\title{
Impacts of aerosol particles on the microphysical and radiative properties of stratocumulus clouds over the southeast Pacific Ocean
}

\author{
C. H. Twohy ${ }^{1}$, J. R. Anderson ${ }^{2}$, D. W. Toohey ${ }^{3}$, M. Andrejczuk ${ }^{4, *}$, A. Adams ${ }^{1}$, M. Lytle ${ }^{1}$, R. C. George ${ }^{5}$, R. Wood ${ }^{5}$, \\ P. Saide ${ }^{6}$, S. Spak ${ }^{6}$, P. Zuidema ${ }^{7}$, and D. Leon ${ }^{8}$ \\ ${ }^{1}$ College of Earth, Oceanic and Atmospheric Sciences, Oregon State University, Corvallis, Oregon, USA \\ ${ }^{2}$ School for Engineering of Matter, Transport and Energy, Arizona State University, Tempe, Arizona, USA \\ ${ }^{3}$ Department of Atmospheric and Oceanic Sciences, University of Colorado, Boulder, Colorado, USA \\ ${ }^{4}$ School of Earth and Environment, University of Leeds, Leeds, UK \\ ${ }^{5}$ Department of Atmospheric Sciences, University of Washington, Seattle, Washington, USA \\ ${ }^{6}$ Center for Global and Regional Environmental Research, University of Iowa, Iowa City, Iowa, USA \\ ${ }^{7}$ Rosenstiel School of Marine and Atmospheric Sciences, University of Miami, USA \\ ${ }^{8}$ Department of Atmospheric Science, University of Wyoming, Laramie, Wyoming, USA \\ * currently at: Atmospheric, Oceanic and Planetary Physics, Department of Physics, University of Oxford, Oxford, UK
}

Correspondence to: C. H. Twohy (twohy@coas.oregonstate.edu)

Received: 6 July 2012 - Published in Atmos. Chem. Phys. Discuss.: 9 August 2012

Revised: 5 February 2013 - Accepted: 8 February 2013 - Published: 5 March 2013

\begin{abstract}
The southeast Pacific Ocean is covered by the world's largest stratocumulus cloud layer, which has a strong impact on ocean temperatures and climate in the region. The effect of anthropogenic sources of aerosol particles on the stratocumulus deck was investigated during the VOCALS field experiment. Aerosol measurements below and above cloud were made with a ultra-high sensitivity aerosol spectrometer and analytical electron microscopy. In addition to more standard in-cloud measurements, droplets were collected and evaporated using a counterflow virtual impactor (CVI), and the non-volatile residual particles were analyzed.

Many flights focused on the gradient in cloud properties on an E-W track along $20^{\circ} \mathrm{S}$ from near the Chilean coast to remote areas offshore. Mean statistics, including their significance, from eight flights and many individual legs were compiled. Consistent with a continental source of cloud condensation nuclei, below-cloud accumulation-mode aerosol and droplet number concentration generally decreased from near shore to offshore. Single particle analysis was used to reveal types and sources of the enhanced particle number that influence droplet concentration. While a variety of particle types were found throughout the region, the dominant particles near shore were partially neutralized sulfates. Modeling and chemical analysis indicated that the predominant source
\end{abstract}

of these particles in the marine boundary layer along $20^{\circ} \mathrm{S}$ was anthropogenic pollution from central Chilean sources, with copper smelters a relatively small contribution.

Cloud droplets were smaller in regions of enhanced particles near shore. However, physically thinner clouds, and not just higher droplet number concentrations from pollution, both contributed to the smaller droplets. Satellite measurements were used to show that cloud albedo was highest $500-1000 \mathrm{~km}$ offshore, and actually slightly lower closer to shore due to the generally thinner clouds and lower liquid water paths there. Thus, larger scale forcings that impact cloud macrophysical properties, as well as enhanced aerosol particles, are important in determining cloud droplet size and cloud albedo.

Differences in the size distribution of droplet residual particles and ambient aerosol particles were observed. By progressively excluding small droplets from the CVI sample, we were able to show that the larger drops, some of which may initiate drizzle, contain the largest aerosol particles. Geometric mean diameters of droplet residual particles were larger than those of the below-cloud and above cloud distributions. However, a wide range of particle sizes can act as droplet nuclei in these stratocumulus clouds. A detailed LES microphysical model was used to show that this can 
occur without invoking differences in chemical composition of cloud-nucleating particles.

\section{Introduction}

Stratocumulus clouds play an important role in the Earth's radiation budget. Their ability to reflect incoming shortwave radiation from the sun helps to cool the surface of the planet and offset warming by greenhouse gases (Hartmann et al., 1992). The albedo of stratocumulus clouds is dependent on the liquid water path (LWP, vertically integrated liquid water content) and the effective droplet radius $r_{\mathrm{e}}$ (Stephens, 1978). Since aerosol particles act as cloud condensation nuclei (CCN), they influence both droplet number concentration and size. The first indirect effect of aerosols on clouds, recognized by Twomey (1974), postulates that an increase in cloud condensation nuclei for clouds with constant liquid water path will result in a decrease in $r_{\mathrm{e}}$, and thus an increased albedo. While simple in theory, observations of this effect are confounded by variability in LWP over the short time and space scales accessible by aircraft measurements (Twohy et al., 2005; Stevens and Feingold, 2009). Satellite measurements, while able to measure over longer time and space scales, may suffer biases especially near broken clouds (Marshak et al., 2008; Twohy et al., 2009; Quaas et al., 2010), which can artificially increase derived aerosol number concentration near clouds. Additionally, aerosol particles themselves may impact cloud macrophysical properties through radiative/microphysical interactions (Ackerman et al., 2000, 2003; Lee et al., 2009), and the sign of these responses can be positive or negative (Ackerman et al., 2004; Wood, 2007; Chen et al., 2012). Knowledge of the effects of atmospheric aerosols, particularly anthropogenic aerosols, on stratocumulus albedo is a prominent need for accurate climate change assessments (Solomon et al., 2007).

The southeast Pacific Ocean (SEP) is an ideal environment to study stratocumulus clouds because it has one of the world's most persistent and unexplored cloud decks (Huneeus et al., 2006; Wood et al., 2011b). Chile, which borders a large portion of the SEP, has an economy heavily based in mining copper and other metals (Schüller et al., 2008). These sources and various other industrial and urban activity produce primary and secondary aerosol particles including sulfate, organic, and industrial types (Schüller et al., 2008; Hawkins et al., 2010; Tsapakis et al., 2002). Under the predominately southeasterly flow regime, these particles have the potential to influence the SEP stratocumulus deck through their potential action as CCN. Satellite datasets predict high concentrations of cloud droplets in the near-coastal regions of the SEP that would be sufficient to perturb the diurnal mean reflected shortwave radiation by $10-20 \mathrm{~W} \mathrm{~m}^{-2}$ in the absence of liquid water changes (George and Wood, 2010). Additionally, aerosol pollutants may alter the forma- tion and persistence of pockets of open cells (POCs) within stratocumulus (Stevens et al., 2005b; Wood et al., 2011a), potentially influencing cloud fraction and albedo.

Huneeus et al. (2006) found a spatial correlation between sulfur emissions and decreased effective radii off the Chilean coast measured by satellite remote sensors. Backtrajectory analysis suggested that near the Chilean shore, marine boundary layer air along the $20^{\circ} \mathrm{S}$ parallel is usually influenced by continental sources, and indeed, research aircraft measured higher aerosol concentrations and droplet concentrations near shore than farther offshore (Bretherton et al., 2010; Allen et al., 2011). Kleinman et al. (2012) noted that the near shore region was enhanced in carbon monoxide and sulfate particles, which they attributed to South American coastal pollution sources.

\section{Methods and objectives}

A US National Science Foundation C-130 aircraft operated by the National Center for Atmospheric Research collected data on the SEP stratocumulus deck during October and November of 2008. This was one component of the VAMOS Ocean-Cloud-Atmosphere-Land Systems (VOCALS) project, with the overarching purpose of improving understanding of SEP clouds and their simulation in global climate models (Wood et al., 2011b). One of the specific VOCALS goals was to determine how continental pollution from industrial activity affected droplet size (and presumably, cloud albedo) in the stratocumulus layer offshore. In particular, the first portion of the following VOCALS hypothesis (1c) is examined here:

The small effective radii measured from space over the SEP are primarily controlled by anthropogenic, rather than natural, aerosol production.

Related objectives of this work were to determine the sizes and types of particles that are present to act as cloud condensation nuclei near shore, and how much copper smelters prevalent in the region actually contribute to CCN. Impacts of additional particles on droplet number, drizzle and cloud albedo near shore are also examined.

While a variety of aircraft participated in the VOCALS experiment, this paper focuses on the data collected from the C-130 aircraft to address the above relationships. Data from C-130 flights that transited from near the Chilean coast to offshore along the $20^{\circ} \mathrm{S}$ latitude line were used to examine gradients of cloud microphysical and aerosol properties relative to distance from the coast. Flights were based out of Arica, Chile $\left(70^{\circ} \mathrm{W}\right.$ longitude), and extended as far as $85^{\circ} \mathrm{W}$, about $1600 \mathrm{~km}$ offshore. Level flight legs of ten minutes duration (about $70 \mathrm{~km}$ in horizontal extent) were made sequentially below, in, and above the stratocumulus cloud layer. Subcloud legs were at approximately $150 \mathrm{~m}$ altitude, while incloud legs were about $300 \mathrm{~m}$ above cloud base as measured by soundings through the layer. The above-cloud legs were 
Table 1. Cloud and sub-cloud leg times (UTC) used in paper.

\begin{tabular}{|c|c|c|c|c|c|}
\hline Cloud Leg ${ }^{\mathrm{a}}$ & Start Time & End Time & Sub-Cloud Leg & Start Time & End Time \\
\hline $1 \mathrm{C}-2$ & $18: 46: 50$ & $18: 56: 50$ & 1SC-2 & 18:29:17 & $18: 43: 00$ \\
\hline $3 C-1^{b}$ & $06: 35: 10$ & $06: 45: 10$ & $3 \mathrm{SC}-1^{\mathrm{b}}$ & $06: 49: 53$ & $06: 59: 53$ \\
\hline $3 C-3$ & $08: 14: 50$ & $08: 24: 50$ & $3 \mathrm{SC}-3$ & 08:30:00 & 08:41:00 \\
\hline $3 C-4$ & 09:03:40 & 09:13:40 & $3 \mathrm{SC}-4$ & $09: 20: 14$ & $09: 31: 30$ \\
\hline $3 C-5$ & $10: 28: 00$ & $10: 38: 00$ & $3 \mathrm{SC}-5$ & $10: 44: 43$ & $10: 56: 02$ \\
\hline $3 C-6$ & $11: 21: 20$ & $11: 33: 40$ & $3 S C-6$ & $11: 38: 40$ & $11: 52: 00$ \\
\hline $3 C-8$ & $13: 13: 20$ & $13: 26: 20$ & $3 \mathrm{SC}-8$ & $13: 30: 00$ & 13:40:00 \\
\hline $4 \mathrm{C}-1$ & 06:49:00 & 06:59:00 & $4 \mathrm{SC}-1$ & 07:03:15 & $07: 13: 15$ \\
\hline $4 C-2$ & 07:31:00 & 07:41:00 & $4 \mathrm{SC}-2$ & $07: 45: 20$ & $07: 55: 20$ \\
\hline $4 C-3$ & $08: 23: 40$ & $08: 33: 40$ & $4 \mathrm{SC}-3$ & 08:39:00 & 08:49:00 \\
\hline $4 C-4$ & 09:10:00 & 09:20:00 & $4 \mathrm{SC}-4$ & $09: 26: 30$ & $09: 36: 30$ \\
\hline $4 C-6$ & 10:53:00 & 11:03:00 & $4 \mathrm{SC}-6$ & 11:08:30 & $11: 18: 30$ \\
\hline $4 C-7$ & $11: 48: 20$ & $11: 58: 20$ & $4 \mathrm{SC}-7^{\mathrm{c}}$ & 12:09:00 & $12: 14: 00$ \\
\hline $4 C-9$ & $13: 28: 00$ & $13: 38: 00$ & 4SC-9 & $13: 41: 20$ & $13: 46: 45$ \\
\hline $5 C-1$ & 07:07:10 & $07: 17: 10$ & $5 \mathrm{SC}-1$ & $07: 20: 56$ & 07:30:56 \\
\hline $5 C-2$ & 07:48:05 & 07:58:05 & $5 \mathrm{SC}-2$ & 08:03:00 & 08:13:00 \\
\hline $5 C-3$ & $08: 45: 30$ & $08: 55: 30$ & $5 \mathrm{SC}-3$ & 09:00:50 & 09:10:50 \\
\hline $5 C-4$ & 09:29:00 & 09:39:00 & $5 \mathrm{SC}-4$ & $09: 44: 30$ & 09:54:30 \\
\hline $5 C-5$ & 10:11:50 & $10: 21: 50$ & $5 \mathrm{SC}-5$ & $10: 28: 15$ & $10: 32: 40$ \\
\hline $5 C-7$ & $11: 11: 50$ & $11: 21: 50$ & $5 \mathrm{SC}-7$ & $11: 26: 55$ & $11: 36: 55$ \\
\hline $5 C-8$ & 11:57:05 & $12: 07: 05$ & $5 \mathrm{SC}-8$ & $12: 12: 40$ & $12: 22: 40$ \\
\hline $5 C-9$ & $12: 57: 02$ & $13: 07: 02$ & 5SC-9 & $13: 12: 45$ & $13: 22: 45$ \\
\hline $5 C-10$ & $13: 41: 57$ & $13: 51: 57$ & $5 \mathrm{SC}-10$ & $13: 57: 14$ & 14:07:14 \\
\hline $5 C-11$ & $14: 38: 20$ & $14: 49: 20$ & $5 \mathrm{SC}-11$ & $14: 53: 40$ & $15: 03: 40$ \\
\hline $9 C-3$ & $12: 26: 25$ & $12: 36: 25$ & $9 \mathrm{SC}-2$ & $12: 40: 30$ & $12: 50: 30$ \\
\hline $9 \mathrm{C}-4$ & $13: 20: 00$ & $13: 30: 00$ & $9 \mathrm{SC}-3$ & $13: 33: 53$ & $13: 44: 06$ \\
\hline $10 \mathrm{C}-2$ & $07: 48: 55$ & 07:58:55 & $10 \mathrm{SC}-2$ & $08: 02: 43$ & $08: 12: 43$ \\
\hline $10 \mathrm{C}-4$ & $09: 22: 36$ & $09: 32: 36$ & 10SC-4 & $09: 37: 55$ & $09: 47: 55$ \\
\hline $10 \mathrm{C}-5$ & $10: 16: 30$ & $10: 26: 30$ & $10 \mathrm{SC}-5^{\mathrm{c}}$ & $10: 31: 20$ & $10: 37: 20$ \\
\hline $10 C-6$ & $10: 59: 20$ & 11:09:20 & $10 \mathrm{SC}-6$ & $11: 14: 10$ & $11: 24: 10$ \\
\hline $10 \mathrm{C}-7$ & $11: 54: 20$ & $12: 04: 20$ & $10 \mathrm{SC}-7$ & $12: 08: 40$ & $12: 18: 40$ \\
\hline $10 \mathrm{C}-8$ & $12: 36: 10$ & $12: 46: 10$ & $10 \mathrm{SC}-8$ & $12: 50: 25$ & 13:00:30 \\
\hline $10 \mathrm{C}-9$ & $13: 36: 52$ & $13: 51: 52$ & 10SC-9 & $13: 24: 00$ & $13: 34: 00$ \\
\hline $13 \mathrm{C}-1$ & $13: 37: 29$ & $13: 47: 29$ & 13SC-1 & $13: 50: 40$ & 14:00:40 \\
\hline $13 \mathrm{C}-2$ & $14: 17: 45$ & $14: 27: 45$ & 13SC-2 & $14: 32: 10$ & $14: 42: 10$ \\
\hline $13 \mathrm{C}-3$ & $15: 12: 15$ & $15: 22: 15$ & $13 \mathrm{SC}-3^{\mathrm{c}}$ & $15: 26: 15$ & $15: 35: 20$ \\
\hline $14 \mathrm{C}-1$ & $13: 35: 00$ & $13: 45: 00$ & 14SC-1 & $13: 49: 40$ & $13: 59: 40$ \\
\hline $14 \mathrm{C}-2$ & $14: 16: 50$ & $14: 28: 30$ & 14SC-2 & $14: 33: 30$ & $14: 44: 40$ \\
\hline $14 \mathrm{C}-3$ & $15: 14: 30$ & $15: 24: 30$ & $14 \mathrm{SC}-3$ & $15: 28: 50$ & $15: 41: 30$ \\
\hline
\end{tabular}

${ }^{a}$ First number in leg code is the C-130 research flight number. Flt 1: 15 October 2008. Flt 3: 21 October 2008. Flt 4: 23 October 2008. Flt 5: 26 October 2008. Flt 9: 4 November 2008. Flt 10: 6 November 2008. Flt 13: 13 November 2008. Flt 14: 15 October 2008.

b PCASP data missing for flight 3.

${ }^{\mathrm{c}}$ Flight scientist's sub-cloud leg times adjusted to avoid drizzle artifacts on aerosol probes.

about $300 \mathrm{~m}$ above cloud-top, in free tropospheric air. For the purpose of our analysis, each leg was considered a sampling period, and $1 \mathrm{~Hz}$ data from the various probes were averaged over the entire leg as long as in-cloud data were available. Data from about 40 sub-cloud and cloud legs on eight flights were composited to statistically evaluate changes with distance from shore (with actual number of samples varying slightly depending on the parameter due to measurement availability). These pairs of legs along $20^{\circ} \mathrm{S}$ were chosen based on matching within 20 min in time and also having data from key instruments available. Cloud legs (as numbered by the C-130 flight scientist) and times used are given in Table 1. For cloud-leg averages, only data points when the cloud liquid water content was $>0.05 \mathrm{~g} \mathrm{~m}^{-3}$ were averaged, to avoid including cloud gaps. This is similar to what other VOCALS researchers (Bretherton et al., 2010; Allen et al., 2011) have used. Maximum droplet concentration was calculated using 
a 5-second pre-averaging technique for noise reduction as in Hegg et al. (2012).

A wing-mounted Particle Measuring Systems (PMS) Passive Cavity Aerosol Spectrometer Probe (PCASP-100) and a cabin mounted Ultra High Sensitivity Aerosol Spectrometer (UHSAS) counted and sized particles from 0.1-3.0 $\mu \mathrm{m}$ and $0.055-1.0 \mu \mathrm{m}$ dry diameter, respectively. Sizing for both instruments were based on calibrations with polystyrene latex spheres before and after the campaign. For smaller particles, a Thermo-Systems Inc. 3760A Condensation Particle Counter (CPC) was utilized to quantify total particle concentration larger than $0.01 \mu \mathrm{m}$ in diameter. Cloud droplets between 2 and $50 \mu \mathrm{m}$ in diameter were measured optically using a Droplet Measurement Technologies Cloud Droplet Probe (CDP). Note that the CDP may underestimate droplet concentration and overestimate droplet size due to the occurrence of coincident particles in the instrument sample volume (Lance et al., 2010). This effect is expected to be small for the offshore droplet concentrations, but may be as large as $25 \%$ for droplet concentrations near $300 \mathrm{~cm}^{-3}$ that were sometimes measured near shore. Drizzle drops larger than about $60 \mu \mathrm{m}$ were measured using a modified PMS 2D-C optical array probe.

Cloud droplets between about 7 and $50 \mu \mathrm{m}$ in diameter were collected and evaporated with a counterflow virtual impactor, CVI (Noone et al., 1988). The lower size limit was sometimes increased by the operator to investigate changes in properties with droplet size. The CVI inlet was heated to about $55^{\circ} \mathrm{C}$ in order to evaporate liquid water present in droplets (which also were impacted into dry nitrogen inside the CVI). At $55^{\circ} \mathrm{C}$, some volatile organic species may be evaporated, in addition to water. However, organic material comprised a relatively small fraction of submicron aerosol mass in the VOCALS sampling region (Allen et al., 2011). Because the CVI samples sub-isokinetically, it enhances cloud particles and their residual particles by a factor of about 25 for C-130 sampling conditions. Downstream of the CVI inlet, the UHSAS measured size distributions of dry, non-volatile residual particles between $0.055-1.0 \mu \mathrm{m}$ in diameter. Uncertainty in the number of residual particles is related to uncertainty in the CVI enhancement factor of about $8 \%$ (Twohy et al., 2003), and uncertainty in the optical counters themselves, which is addressed in the figure captions.

Problems with the CDP and PCASP instruments were encountered on Flights 3 and 4 (21 and 23 October 2008, respectively). Leg-average data for the CDP droplet concentration and mean sizes on these flights were filled in by regressing these parameters vs. the corresponding FSSP parameters on the other six flights. Likewise, leg-average data for the PCASP particle concentration on flight $3 \& 4$ were filled in by regressing PCASP concentration vs. the UHSAS particle concentration on the other six flights.

Both ambient and CVI residual particles were collected with a three-stage micro-impactor (California Measurements, Model MPS-3) and a single stage filter sampler
(PIXE International, Streaker Air-Particulate Sampler) operated in discrete mode under computer control. For the micro-impactor samples, particles impacted on the second stage ( $\sim 0.5$ to $1.0 \mu \mathrm{m}$ diameter) and third stage (smaller than $\sim 0.5 \mu \mathrm{m}$ ) were analyzed by transmission electron microscope (TEM, JEOL Model 2010) and elemental X-ray analysis (by energy dispersive spectrometry, EDS) for a number of flights. Selected filter samples were analyzed by automated scanning electron microscope (SEM, JEOL Model JSM-5800) controlled by a spectral imaging system (ThermoElectron NORAN System 7) and with a large-window silicon drift detector for EDS. The general approach of the automated SEM techniques are described by Anderson et al. (1996).

Two types of numerical models were utilized in this work. First, simulations using the WRF-Chem v3.3 model (Grell et al., 2005; Skamarock et al., 2008) provided high-resolution meteorology for trajectory analysis and were used to perform sensitivity analysis on the impact of smelter emissions on particle concentrations in the VOCALS sampling region. The WRF-Chem model was configured with $12 \mathrm{~km}$ horizontal resolution and uses the CBMZ-MOSAIC (Zaveri et al., 2008; Zaveri and Peters, 1999) framework for gases and aerosols. Smelter emissions were released as $\mathrm{SO}_{2}$, which is converted to sulfate through gaseous (Zaveri and Peters, 1999) and aqueous chemistry (Fahey and Pandis, 2001) and reacts to form new particles, as well as condenses on existing particles. The WRF-Chem simulations used in our study were run with chemical boundary conditions from the MOZART global model, so long-range sources (e.g., Allen et al., 2011) were included in the analysis. The model considers both the direct (Fast et al., 2006) and indirect effects (Chapman et al., 2009) of aerosols. Details on this configuration and validation against VOCALS measurements are thoroughly described in Saide et al. (2012a).

In addition, a Lagrangian cloud model (LCM) utilizing a large eddy simulation (LES) numerical model with Lagrangian representation of microphysics (Andrejczuk et al., 2008, 2010) was used to simulate droplet activation and evolution in VOCALS stratocumulus for comparison with CVI droplet residual size distributions. The microphysical scheme tracks millions of groups of particles and is coupled with Eulerian dynamics and thermodynamics (Reisner et al., 2005). Depending on environmental conditions supplied by the Eulerian part of the model, water can condense/evaporate from the surface of particles, and forces resulting from the phase change, together with the drag forces, are returned to the Eulerian part of the model. For each group of particles, a full condensation model is included, meaning aerosol chemical properties are taken into account when solving the droplet growth equation; however no subsequent chemical reactions are included. The three-dimensional, horizontally periodic model domain was $3.2 \mathrm{~km} \times 3.2 \mathrm{~km}$ in horizontal extent and $2 \mathrm{~km}$ vertically, resolved with $80 \times 80 \times 200$ grid points. 
Table 2. Significance of Fitted Relationships between Various Parameters.

\begin{tabular}{llllllll}
\hline Parameters $(Y$ vs. $X)$ & $r^{2 \mathrm{a}}$ & $r^{\mathrm{b}}$ & $n^{\mathrm{c}}$ & $t_{\text {obs }}^{\mathrm{d}}$ & $t_{\text {crit }}^{\mathrm{e}}$ & Reject? $^{\mathrm{f}}$ & Regression Equation \\
\hline$N_{\mathrm{p}}(>0.055 \mu \mathrm{m})$ vs. Dist & 0.63 & $(-) 0.79$ & 39 & 7.94 & 1.68 & Yes & $Y=1317-373.5 \log (X)$ \\
$N_{\mathrm{p}}(>0.1 \mu \mathrm{m})$ vs. Dist & 0.67 & $(-) 0.82$ & 39 & 8.67 & 1.68 & Yes & $Y=997.5-286.7 \log (X)$ \\
$N_{\mathrm{p}}(>0.01 \mu \mathrm{m})$ vs. Dist & 0.03 & $(-) 0.17$ & 39 & 1.07 & 1.68 & No & \\
$N_{\mathrm{d}}$ vs. Dist & 0.64 & $(-) 0.80$ & 39 & 8.11 & 1.68 & Yes & $Y=628-174.1 \log (X)$ \\
$N_{\mathrm{d}}$ Max vs. Dist & 0.59 & $(-) 0.77$ & 39 & 7.30 & 1.68 & Yes & $Y=831.7-226.4 \log (X)$ \\
$N_{\mathrm{p}}(>0.055 \mu \mathrm{m})$ vs. $N_{\mathrm{d}}(\log$ fit) & 0.64 & $(+) 0.80$ & 39 & 8.11 & 1.68 & Yes & $Y=-382.1+220.8 \log (X)$ \\
$N_{\mathrm{p}}(>0.1 \mu \mathrm{m})$ vs. $N_{\mathrm{d}}$ (log fit) & 0.63 & $(+) 0.79$ & 39 & 7.94 & 1.68 & Yes & $Y=-340.8+216.8 \log (\mathrm{X})$ \\
$N_{\mathrm{p}}(>0.1 \mu \mathrm{m})$ vs. $N_{\mathrm{d}}$ (linear fit) & 0.57 & $(+) 0.75$ & 39 & 7.00 & 1.68 & Yes & $Y=52.6+0.459 X$ \\
$N_{\mathrm{p}}(>0.1 \mu \mathrm{m})$ vs. $N_{\mathrm{d}}$ Max (linear fit) & 0.53 & $(+) 0.73$ & 39 & 6.46 & 1.68 & Yes & $Y=84+0.5942 X$ \\
Mean drop diam vs. Dist & 0.42 & $(+) 0.65$ & 39 & 5.18 & 1.68 & Yes & $Y=-10.4+8.883 \log (x)$ \\
$r_{\mathrm{e}}$ vs. Dist & 0.40 & $(+) 0.63$ & 39 & 4.97 & 1.68 & Yes & $Y=-4.8+4.584 \log (X)$ \\
Drizzle Conc vs. Dist & 0.04 & $(+) 0.20$ & 36 & 1.19 & 1.69 & No & \\
Drizzle Diam vs. Dist & 0.40 & $(+) 0.63$ & 36 & 4.76 & 1.69 & Yes & $Y=-90+62.33 \log (X)$ \\
Drizzle LWC vs. Dist & 0.10 & $(+) 0.32$ & 36 & 1.94 & 1.69 & Yes & $Y=-0.392+0.1654 \log (X)$ \\
Cloud Thickness vs. Dist & 0.27 & $(+) 0.52$ & 27 & 3.04 & 1.70 & Yes & $Y=-136+162.3 \log (X)$ \\
LWP vs. Dist & 0.22 & $(+) 0.47$ & 39 & 3.23 & 1.68 & Yes & $Y=-237+115.9 \log (X)$ \\
Cloud albedo vs. Dist, Aircraft (log fit) & 0.10 & $(+) 0.32$ & 21 & 1.45 & 1.73 & No & \\
Cloud albedo vs. Dist, Aircraft (log fit) & 0.01 & $(+) 0.09$ & 18 & 0.36 & 1.75 & No & \\
Cloud Albedo vs. Dist MODIS (poly fit) & 0.83 & 0.91 & 15 & 7.33 & 1.80 & Yes & $Y=0.339+0.000546225 X$ \\
& & & & & & & $-5.200984 \times 10^{-7} X^{2}+1.377992 \times 10^{-10} X^{3}$ \\
\hline
\end{tabular}

Parameter Description: Dist = distance west from shore along $20^{\circ} \mathrm{S}, N_{\mathrm{p}}=$ particle concentration, $N_{\mathrm{d}}=$ droplet concentration from CDP probe, other droplet parameters are also from the CDP probe, drizzle parameters from the 2D-C probe, cloud thickness, LWP and albedo as described in Sect. 3.4.

a Pearson coefficient of determination from the appropriate figure/regression.

$\mathrm{b}$ Pearson coefficient of correlation. Also denotes sign of relationship (positive or negative) for linear or logarithmic fit.

c Number of samples.

$\mathrm{d}$ Observed t-value $=r\left((\mathrm{df}) /\left(1-r^{2}\right)\right)^{0.5} . \mathrm{df}=$ degrees of freedom $(n-2$ except for MODIS albedo when it is $n-4$ due to 3rd order fit $)$.

e Critical $\mathrm{t}$ value at $p=0.05$, from statistical tables.

${ }^{\mathrm{f}}$ If $t_{\mathrm{obs}}>t_{\text {crit }}$, null hypothesis may be rejected.

George and Wood (2010) used MODIS satellite data to show that variability in cloud fraction is an important factor in the planetary albedo (including cloudy and clear areas) of this region. Because we focus on aerosol effects on cloud properties, clear-air regions are not included in flight-leg averages presented here. Further analysis of MODIS-derived cloud albedos are presented in this work, using the approach described in Sect. 3.4.

Throughout the paper, correlations between various aerosol and cloud properties and distance from shore are presented. Statistical significance for each relationship is assessed in Table 2 using a simple one-tailed t-test at a probability level of 0.05 . If the $t$ value for the observations, $t_{\mathrm{obs}}$, is greater than the critical t-value, $t_{\text {crit }}$, the correlation may be considered significant. Equations for significant relationships are also included.

\section{Results}

\subsection{Changes in aerosol and cloud characteristics with distance from coast}

Flights along the $20^{\circ} \mathrm{S}$ latitude line typically showed a steady and reproducible decrease in droplet number concentration, $N_{\mathrm{d}}$, when the C-130 aircraft flew from near the coast to a re- mote region offshore. A corresponding increase in $N_{\mathrm{d}}$ was observed on return flights within the boundary layer back toward shore. The number concentration of accumulationmode aerosol particles below cloud was also higher near shore than offshore. Figure 1a shows the mean aerosol particle number concentration, $N_{\mathrm{p}}$, measured below cloud vs. distance from shore (or longitude) using data from eight $\mathrm{C}$ 130 flights. Both the PCASP (larger than $0.1 \mu \mathrm{m}$ ) and UHSAS (larger than $0.055 \mu \mathrm{m}$ ) data are shown. The concentration minimum between the smaller Aitken mode and larger accumulation mode begins at approximately $0.08 \mu \mathrm{m}$ (Kleinman et al., 2012) in this region. Therefore, the PCASP measures most, but not all, of the accumulation mode, while the UHSAS measures all the accumulation mode and the tail end of the Aitken mode. This additional size range encompasses more particles likely to act as CCN. Below-cloud drizzle events were excluded from the aerosol data compiled.

$N_{\mathrm{p}}(>0.055 \mu \mathrm{m})$ decreased from about 400 to $600 \mathrm{~cm}^{-3}$ near shore to 100 to $200 \mathrm{~cm}^{-3} \sim 1500 \mathrm{~km}$ offshore. This suggests, but doesn't alone establish, that the continent is the dominant source of accumulation-mode particles near shore. Allen et al. (2011) and Kleinman et al. (2012) found that both carbon monoxide (a continental tracer) and sulfate aerosol mass also were higher in the boundary layer near shore than offshore. While sulfate aerosol can be produced 

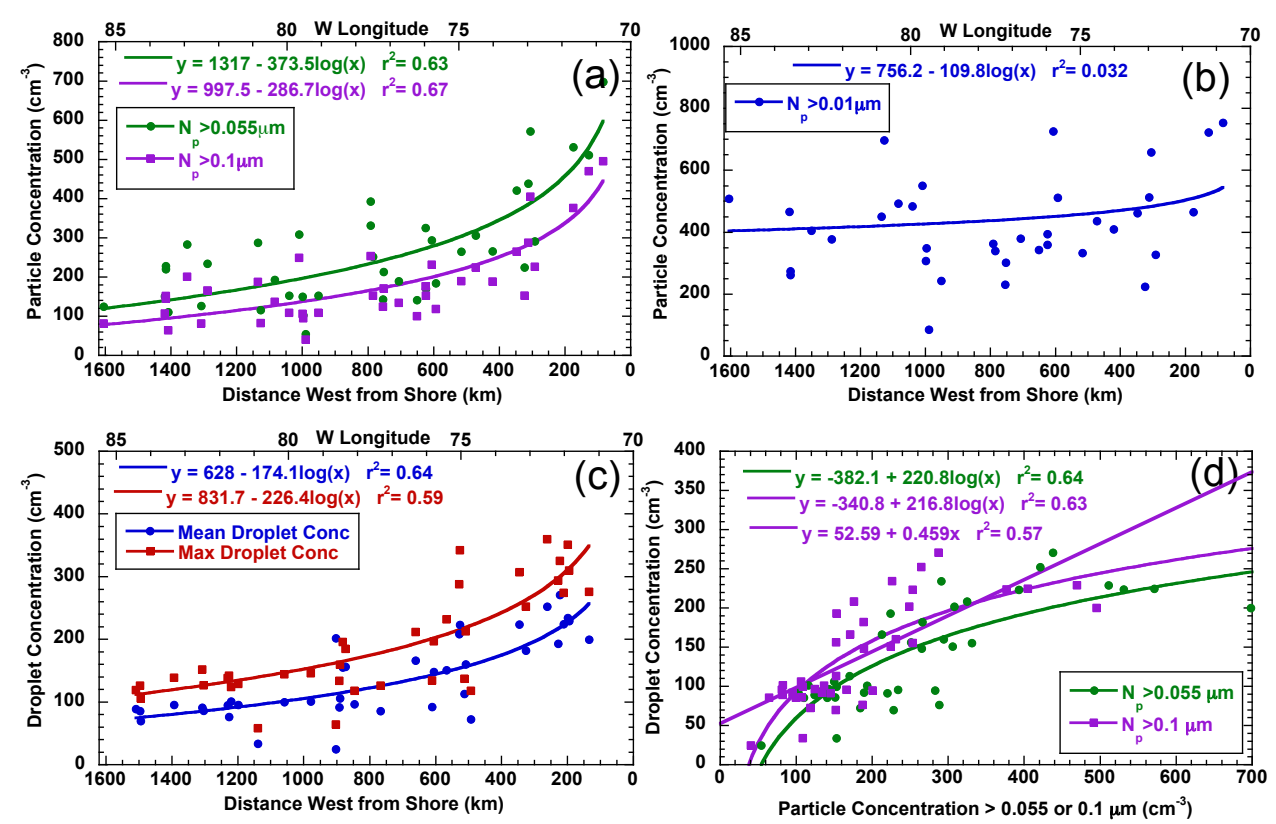

Fig. 1. (a) Mean below-cloud aerosol number concentration vs. distance west from shore along $20^{\circ} \mathrm{S}$ latitude line for legs on eight different VOCALS C-130 flights. Top axis shows longitude. Green represents data from the UHSAS ( $>0.055 \mu \mathrm{m}$ diameter) and purple from the PCASP $(>0.10 \mu \mathrm{m})$. Median standard deviation along the flight legs was 29 for the UHSAS concentration, and its estimated uncertainty is $8 \%$. Median standard deviation along the flight legs was 18 for the PCASP concentration. Its estimated uncertainty from flow rate uncertainties was $10 \%$ for all but flights 3 and 4 , when it was corrected based upon the corresponding UHSAS concentration due to a possible leak. For those two flights we estimate $20 \%$ uncertainty. (b) Below-cloud number concentration from the CPC (>0.01 $\mu$ m). Median standard deviation along the flight legs was 30 for the CPC concentration, and its estimated uncertainty is <6\% (Twohy, 1991). (c) Cloud droplet number concentration from the CDP as a function of distance from shore. Median standard deviation along the flight legs was 28 for the CDP concentration, and its uncertainty is estimated to be a maximum of about $25 \%$ (low bias) at a droplet concentration of $300 \mathrm{~cm}^{-3}$ (Lance et al., 2010). (d) Particle concentration in two different size ranges vs. droplet concentration.

from plankton-derived dimethylsulfide or DMS, Yang et al. (2011a) showed that DMS actually tended to be lower near shore than offshore. These facts, together with the backtrajectories presented by Bretherton et al. (2010), Allen et al. (2011), and below, substantiate the hypothesis that the enhanced accumulation-mode particles near shore are derived from continental and not marine sources. Model studies with interactive aerosols and cloud microphysics have also simulated enhanced aerosol loadings associated with coastal pollution outflow events (Saide et al., 2012a).

Smaller particles, down to $\sim 0.01 \mu \mathrm{m}$ diameter as measured by the CPC, were sometimes present in higher concentrations offshore than near shore (Fig. 1b). This indicates other sources of these ultrafine particles, such as entrainment from above the boundary layer or photochemical production within clean regions, for example in pockets of open cells (Berner et al., 2011). While relationships between $N_{\mathrm{p}}$ larger than 0.1 and $0.055 \mu \mathrm{m}$ and distance from shore are both significant, total particles larger than $0.01 \mu \mathrm{m}$ show no significant trend.

Figure 1c shows that both mean and maximum cloud droplet number concentration also increased with proximity to shore, in accordance with the trends in particles larger than
0.055 and $0.1 \mu \mathrm{m}$. Cloud and particle concentrations were not only highly correlated with distance from shore but also with each other (Fig. 1d). For the PCASP measurements, we have included a logarithmic as well as a linear fit to compare with Hegg et al. (2012), who presented sub-cloud PCASP concentrations vs. droplet concentration from the Twin Otter aircraft. The Hegg et al. (2012) study yielded a higher slope (0.72 vs. 0.47), but they used maximum measured droplet concentrations. Here we have presented mean droplet concentrations, as they are more representative of the variability of the entire cloud deck. In addition, the non-linear fit is more physical at low concentrations (e.g., with an intercept allowing particles to exist without droplets rather than droplets existing without particles). Utilizing a linear fit for PCASP concentration vs. maximum droplet concentration (not shown in figure, but results included in Table 2) for our data set results in a slope of 0.59. A polynomial fit similar to that used in Twohy et al. (2005) for stratocumulus off the coast of California was explored, but would not be suitable to use for the VOCALS data set due to rollover to lower droplet concentrations at PCASP particle concentrations higher than about $400 \mathrm{~cm}^{-3}$. 

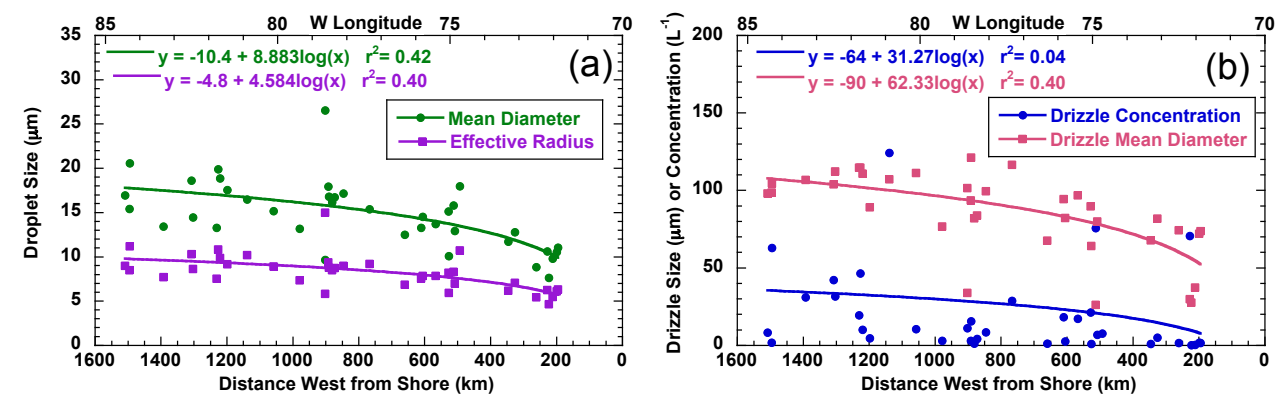

Fig. 2. (a) Mean cloud droplet mean diameter and effective radius from the CDP vs. distance west from shore. Median standard deviation along the flight legs was 2.2 for the mean diameter and 1.3 for effective radius. Sizing uncertainty varies with droplet size and concentration but is estimated to be less than $15 \%$ for most cases (Lance et al., 2010; King et al., 2013). (b) Drizzle drop mean size and number concentration as a function of distance from shore. Mean sizes below the effective detection limit of the probe $(60 \mu \mathrm{m})$ are due to inclusion of zero values when no drizzle was present in cloud. Median standard deviation along the flight legs was 28 for the drizzle mean diameter and 5.4 for concentration. Uncertainty of the 2D-C parameters is complex and depends on many factors, including droplet size; for more information see Baumgardner and Korolev (1997) and Korolev (2007).

Table 2 shows that the relationship between measured $N_{\mathrm{p}}>0.1 \mu \mathrm{m}$ and droplet concentration is statistically significant. A similar strong relationship also applies between measured $N_{\mathrm{p}}>0.055 \mu \mathrm{m}$ and droplet concentration. Single particle analysis (Sect. 3.2) showed that the number concentration of particles $>0.1 \mu \mathrm{m}$ near shore was dominated by particles composed primarily of sulfate. These relatively large, soluble particles are efficient cloud condensation nuclei and explain the strong correlation between accumulation-mode aerosol concentration and droplet number concentration along $20^{\circ} \mathrm{S}$, which has also been observed in other stratocumulus regions (Twohy et al., 2005; Hegg et al., 2012).

Both droplet mean diameter and the radiatively important droplet effective radius $\left(r_{\mathrm{e}}\right)$ increased with distance from shore (Fig. 2a) and decreased with $N_{\mathrm{p}}$ larger than 0.055 or $0.1 \mu \mathrm{m}$ in diameter. This is in accordance with the expected Twomey effect, with increasing cloud condensation nuclei producing smaller droplets. However, as discussed in Sect. 3.4, other factors also play a role. As observed by others (Bretherton et al., 2010), drizzle drops were generally larger and often more prevalent offshore (Fig. 2b). However, drizzle is highly variable with location. Table 2 shows that the trend for larger drizzle offshore is statistically significant, while a trend for greater drizzle concentrations is not. Liquid water content in the drizzle mode, which is related to both drizzle number and size, does show a significant increase with distance from shore (not shown in a figure, but regression results tabulated in Table 2). Stronger longwave cooling, entrainment and turbulence farther offshore (Bretherton et al., 2010 ) is expected to provide more condensate to the layer, allowing some droplets to grow large enough to initiate collision/coalescence and move more water into the drizzle size range. This process is likely inhibited near shore in the more polluted, smaller droplet clouds. Note that cloud macroscale properties (Sect. 3.4) and mesoscale features (Comstock et al., 2007) can also impact droplet size.

In the next section, we explore the chemical composition and sources of the below-cloud aerosol particles, which provide $\mathrm{CCN}$ and influence cloud properties in the region.

\subsection{Aerosol types and chemistry}

\subsubsection{Electron microscopy}

Single-particle techniques are useful in investigating individual particles likely to act as cloud condensation nuclei, since mass measurements may be dominated by only a few larger particles. Highlights of the extensive TEM and SEM analyses of particles collected in the VOCALS region are given below.

During more pristine conditions, for example, those encountered well offshore on flight 11 (9 November 2008), TEM revealed that submicron clear-air particles and CVI cloud droplet residuals were dominated by sea-salt, with seasalt particles as small as $0.05 \mu \mathrm{m}$ observed. In more polluted air masses near shore, ammonium sulfate was much more prevalent (see below). Potassium sulfate, black carbon and non-volatile organic particles smaller than $0.5 \mu \mathrm{m}$ were observed in both CVI and ambient samples (Fig. 3). Potassium sulfate and organic particles containing potassium and sulfate are generally good markers for biomass burning, e.g., Silva et al. (1999). Sulfate was often internally mixed with sea-salt, in excess of sea-water ratios. This internal mixing could occur through condensation of gas-phase sulfuric acid or aqueousphase oxidation of sulfur dioxide in sea-salt aerosol water (Sievering et al., 1999) or cloud water (Benedict et al., 2012). It could also occur through coalescence of large droplets, more likely to form on sea-salt, with smaller droplets more likely to form on sulfate, e.g., Twohy et al. (1989a). Sea- 


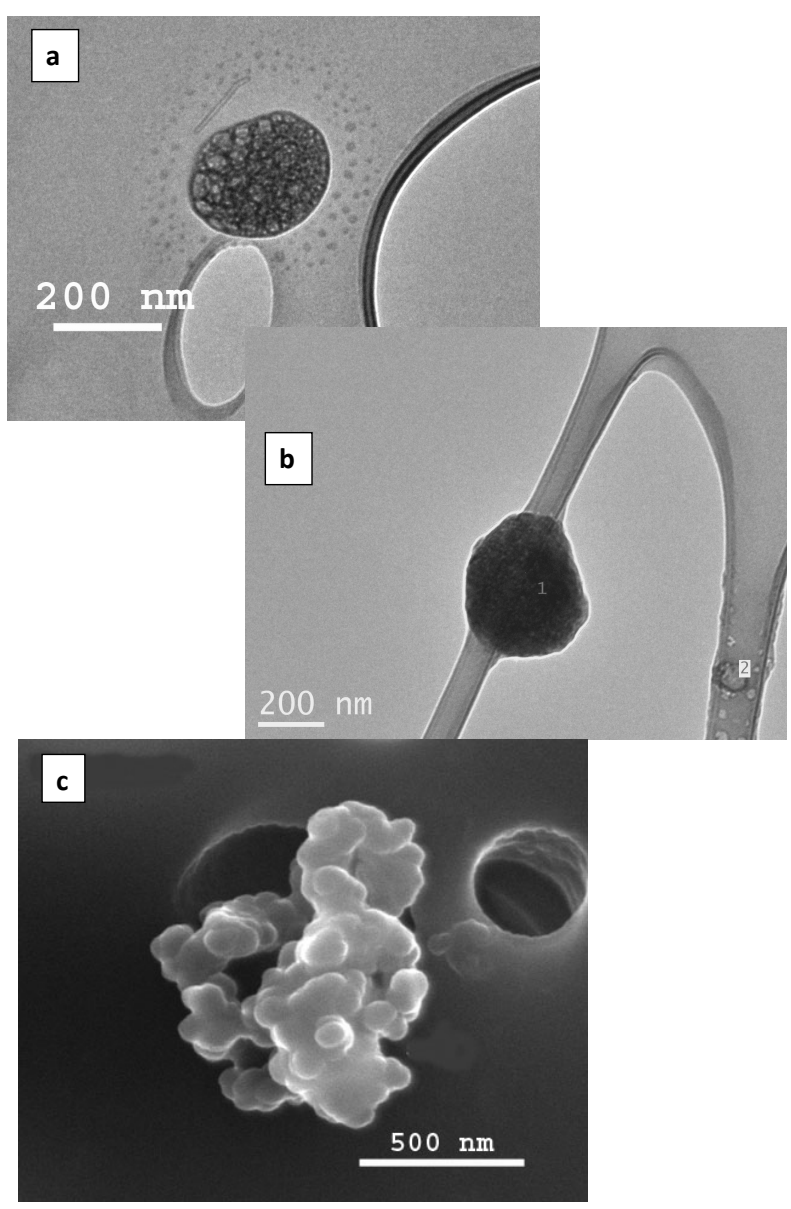

Fig. 3. Examples of particle types found when sampling from the C130 during VOCALS. (a) Ammonium sulfate, (b) biomass burning type, (c) soot carbon from combustion.

salt was sometimes internally mixed with black carbon, most likely from urban pollution or shipping emissions.

Samples were taken above the stratocumulus layer as well. Trajectories reaching above cloud along $20^{\circ} \mathrm{S}$ originated from more diverse locations (northerly, southerly or westerly) than those reaching the boundary layer, which originated primarily from the south-southeast (Bretherton et al., 2010). Above-cloud particles were comprised of soil dust, acidic sulfates, biomass burning and organics, reflecting their diverse origins. Industrial particle types containing aluminum, tin, iron and zinc were sometimes present both in particles above cloud, as well as in the marine boundary layer.

The TEM provides detection of smaller particles and better images than scanning electron microscopy (SEM), but the latter technique has been automated so that large numbers of particles can be analyzed via X-ray analysis. Therefore, more quantitative statistics can be obtained with SEM. Figure 4 shows the percentage of particles by number in two different SEM size ranges for six below-cloud samples col- lected during VOCALS at various distances from shore and pollution levels. For these samples, the SEM was configured with sensitivity to measure particles down to $\sim 0.1 \mu \mathrm{m}$ in size. It is apparent that sulfate dominated in near-shore particles in the 0.1 to $0.2 \mu \mathrm{m}$ diameter range, while offshore, various forms of sea-salt dominated, even at smaller sizes. In the larger particle size range, sulfate and sea-salt were present in roughly equal numbers near shore, but offshore samples were predominately unreacted sea-salt (sea-salt with chloride not replaced with other anions). Sulfate and sea-salt are also expected to be internally mixed with some volatile organic material not detectable by this technique (Russell et al., 2010). However, unlike some regions where organic components may comprise a large fraction of the CCN (e.g. Leaitch et al. (2010), submicron organic aerosol mass was typically only about $10 \%$ of total submicron aerosol mass within the VOCALS region (Allen et al., 2011; Yang et al., 2011b). A small percentage of potassium-containing particles, indicative of biomass burning, were detected, particularly in the offshore regions. Also present in small percentages by number were minor particle types (classified as "Other"), such as soil-dust, organics, black carbon, and metallic elements likely from industrial sources. Sources of these various particle types that can impact cloud properties are explored further in the next section.

\subsubsection{Measurements related to smelters as a source of particles}

Along the $20^{\circ} \mathrm{S}$ parallel, air in the marine boundary layer (MBL) east of $\sim 76^{\circ} \mathrm{W}$ has typically traveled from central Chile (south of $28^{\circ} \mathrm{S}$ ), while air father west usually originates over the open ocean (Bretherton et al., 2010; Allen et al., 2011). Two to five days after emission, continental $\mathrm{SO}_{2}$ emissions are expected to be nearly completely converted to sulfate (Saide et al., 2012a). These sulfate plumes and their influence on clouds can be seen in NOAA ship observations and cloud satellite retrievals, as presented in a comparison between models and measurements by Saide et al. (2012a).

The VOCA emission inventory identifies pollutant contributions by source sector and location (http://www.cgrer. uiowa.edu/VOCA_emis/). Several large copper smelters in northern Chile and Peru account for the majority of regional $\mathrm{SO}_{2}$ emissions. The VOCALS experimental design document hypothesized that "strong sulfur emissions from Chilean and Peruvian copper smelters lead to strongly polluted conditions near the coasts". Emissions from smelters include primary aerosol particle emissions, as well as gaseous $\mathrm{SO}_{2}$ that can be rapidly converted to sulfate aerosol. Since sulfate aerosol particles can be produced from many sources, other tracers are needed. While composition of particles generated by copper smelters have not been extensively studied, Anderson et al. (1988) measured particle chemistry approximately $80 \mathrm{~km}$ downwind of copper smelters in the western United States. They found that particles between 


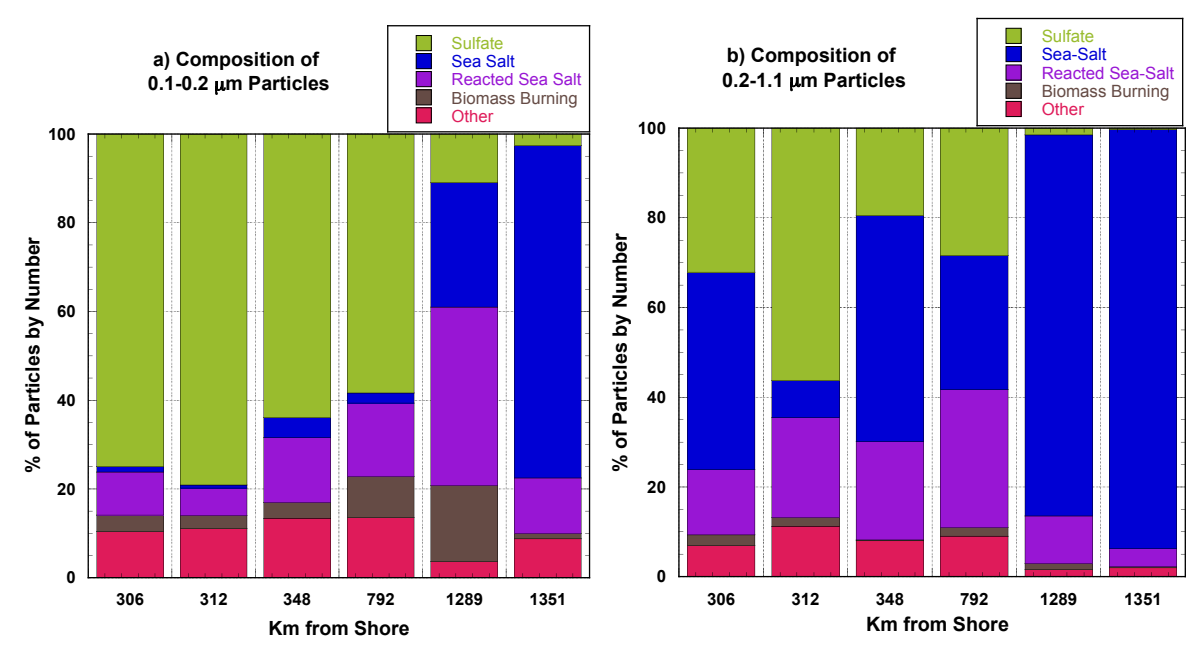

Fig. 4. Particle types by number at $150 \mathrm{~m}$ altitude as determined by SEM/X-ray analysis for six different samples as a function of distance west from shore. (a) Composition of smaller particles approximately 0.1 to $0.2 \mu \mathrm{m}$ in diameter, and (b) composition of particles $0.2 \mu \mathrm{m}$ to $1.1 \mu \mathrm{m}$ in diameter. Between 819 to 1000 particles were analyzed for each sample set. "Reacted sea-salt" refers to sea-salt where chlorine has been partially or completely replaced with sulfate, nitrate or organic material, and "other" category may include soil-dust, organics, black carbon, or industrial material. Date and UTC times are, for $306 \mathrm{~km}: 21$ October 2008 (06:49:50 to 06:59:45, for 312 km: 24 October 2008 (13:41:25-13:46:40), for $348 \mathrm{~km}: 13$ November 2008 (13:50:50-14:01:50), for 792 km: 4 November 2008 (13:34:00-13:45:50), for $1289 \mathrm{~km}$ : 21 October 2008 (10:44:45-10:55:40), and for $1351 \mathrm{~km}: 21$ October 2008 (09:20:20-09:30:45).

about 0.4 and $1.0 \mu \mathrm{m}$ in diameter were enhanced in lead (detectable in about $10 \%$ by number of particles measured) and copper (about $6 \%$ by number). Levels of particulate lead from the only smelter covered by the Anderson study still operating today continue to be high (unpub. data, Arizona Dept. of Environmental Quality), despite significant improvements in emission controls, so we assume lead is likely to be released by South American copper smelters as well.

Automated SEM results from over 70000 particles on eight different C-130 flights from a variety of levels and locations in the VOCALS study region were examined for the presence of copper and lead. The detection limit for copper with the large-window silicon drift EDS employed is about 0.2 to 0.4 weight percent (wt \%) relative to a known standard of effectively infinite thickness. $0.4 \mathrm{wt} \%$ copper was used to filter the $70000+$ particles. Lead has a slightly higher detection limit than copper $(0.5 \mathrm{wt} \%)$. The apparent total wt \% of a particle depends its size, composition and, to some extent, its morphology. Based on simple regression analysis and excluding oxygen and carbon, the total wt $\%$ of an average $0.5 \mu \mathrm{m}$ diameter non-carbonaceous particle is 4.2. A typical $1.0 \mu \mathrm{m}$ diameter particle has an apparent total wt $\%$ of 8.0.

Of the 70000 VOCALS particles analyzed, only $0.1 \%$ contained detectable $\mathrm{Pb}$ and only about $0.1 \%$ contained detectable $\mathrm{Cu}$. Particulate lead can come from a variety of sources, and urban pollution aerosols can contain $\mathrm{Cu}$-bearing particles from vehicular sources (such as brake pad wear) and non-vehicular sources, e.g., Anderson et al. (2006). In contrast, about $2 \%$ of analyzed particles contained $\mathrm{Si}$, a marker for soil dust from continental sources. For these VOCALS
SEM samples, particles were analyzed down to $\sim 0.2 \mu \mathrm{m}$ in diameter, a smaller size than analyzed in the Anderson et al. (1988) study. However, these results suggest that copper smelters may not have been such a large influence along $20^{\circ} \mathrm{S}$ as was originally thought. Reasons for this result are explored below through trajectory analysis and WRF-CHEM modeling.

\subsubsection{Trajectories and modeling related to smelters as a source of particles}

FLEXPART forward trajectories (Stohl et al., 2005; Fast and Easter, 2006) were driven by the Weather Research and Forecasting model meteorology (Saide et al., 2012a) for major smelters in the region. The largest, Ilo, is located to the north of the study region with trajectories to the northwest, while two others (Chuquicamata and Potrerillos) are at elevations that lead to eastward advection over the South American continent (Fig. 5). Trajectories from these sources may have a southward meridional component (Toniazzo et al., 2011) that could take pollution from these sources to latitudes where they can be transported to the study area, but the eastward component dominates. In episodic cases where the southward flux dominates, the plume would be diluted and mixed with fresh emissions that, as discussed below, are also further diluted by the time the plume reaches the VOCALS study area. Even when plumes from northern sources do reach the Pacific, they advect northward with the mean meridional flow (Spak et al., 2010). Thus, we may conclude these three northern smelters rarely impacted VOCALS flights along 


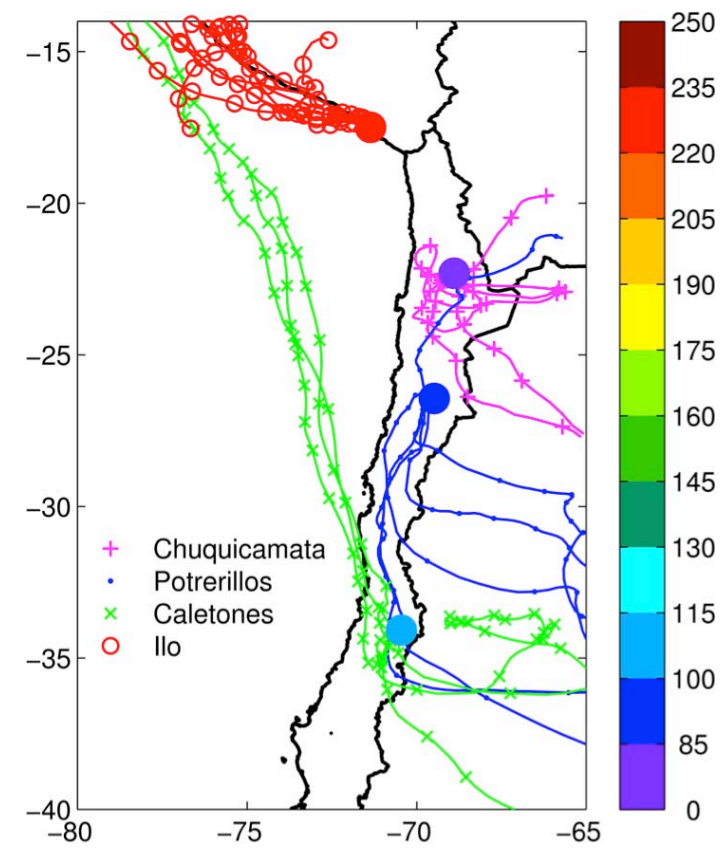

Fig. 5. Forward trajectories starting at major smelters that could potentially affect the VOCALS region. Trajectories are 5 days long during the VOCALS intensive period, starting every 5 days. Markers are plotted every $6 \mathrm{~h}$. Symbols represent different major smelter locations, with colors portraying the sulfur emissions of each (assumed to be emitted as $\mathrm{SO}_{2}$ ) in $\mathrm{Gg} \mathrm{yr}^{-1}$.

$20^{\circ} \mathrm{S}$. There are, however, three copper smelters in central Chile: Caletones, Ventanas, and Chagres, with $\mathrm{SO}_{2}$ emissions of $108,10.6$, and $3.2 \mathrm{Gg} \mathrm{yr}^{-1}$, respectively. These represent about $47 \%$ of $\mathrm{SO}_{2}$ emissions from central Chile. The largest smelter in the region, Caletones, is located in the Andes foothills south of Santiago at 1700 ma.s.l. The FLEXPART trajectories show that air originating at Caletones either crosses eastward into Argentina or may occasionally be entrained into the southeast Pacific MBL east of $75^{\circ} \mathrm{W}$ (approximately half of the study days), depending on the location of the subtropical Pacific high (Spak et al., 2010).

FLEXPART back dispersion analysis was carried out with 10000 trajectories (not shown) originating from times and locations where electron microscopy samples were taken from the C-130 aircraft. Results indicate that when the measurements are affected by inland sources, other coastal sources have a higher impact than smelters in the Andes such as Caletones. These include area sources, coastal power plants, steel mills and industrial boilers. Smelter emissions present over the study region would have been highly diluted, aged, and mixed with primary and secondary aerosols from other sources that have similar emissions rates, but are less diluted and aged upon arrival.

Results from the WRF-Chem model also suggest that smelters were not the major source of enhanced particles over the ocean along $20^{\circ} \mathrm{S}$. Figure 6 shows the mean $\%$ differ-

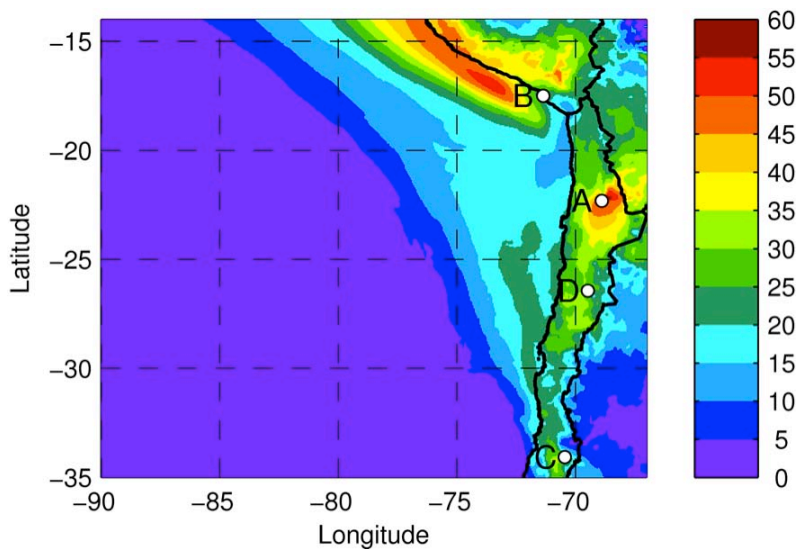

Fig. 6. \% change in particle number concentration predicted by WRF-Chem with and without smelter emissions included. Particle size range was matched to the PCASP probe, 0.12 to $3.0 \mu \mathrm{m}$ in diameter. Major smelters are shown as circles with (A) Chuquicamata, (B) Ilo, (C) Caletones and (D) Potrerillos.

ence for particle number concentration in the boundary layer predicted with and without smelter emissions included for WRF-Chem model runs of 15 October 2008 to 15 November 2008 , the time period coinciding with the VOCALS C-130 flight dates. The size range considered is the same as for the PCASP instrument, 0.12 to $3.0 \mu \mathrm{m}$ diameter. Along $20^{\circ} \mathrm{S}$, smelters are predicted to enhance particle number concentration over the ocean by only 15 to $20 \%$ at most (between about $71^{\circ} \mathrm{W}$ and $77^{\circ} \mathrm{W}$ ). Interestingly, a slightly larger effect is seen both to the north and to the south of the $20^{\circ} \mathrm{S}$ line where the intensive VOCALS measurements focused. The largest effect of smelter emissions is predicted to be near shore around $17^{\circ} \mathrm{S}$, downwind of the Ilo smelter, and over land near Chuquicamata, where trajectories tend to recirculate.

Figure 7 shows the mean predicted values in $2.5^{\circ}$ increments with and without smelter emissions in the boundary layer along the $20^{\circ} \mathrm{S}$ parallel. Particle number concentration $(0.12$ to $3.0 \mu \mathrm{m})$ is given in Fig. $7 \mathrm{a}$ and sulfate mass in Fig. $7 \mathrm{~b}$. The absolute change in particle number concentration due to smelter emissions is at a maximum at $72.5^{\circ} \mathrm{W}$ (near the shoreline), where smelters are predicted to typically contribute about $68 \mathrm{~cm}^{-3}$ to the available particle population of about $320 \mathrm{~cm}^{-3}$ total $(21 \%)$. Sulfate mass at $72.5^{\circ} \mathrm{W}$, on the other hand, is predicted to increase by $40 \%$ with smelter emissions included, indicating that a substantial fraction of sulfur may deposit on existing particles downwind of the smelters themselves. The mean change along $20^{\circ} \mathrm{S}$ between $70^{\circ} \mathrm{W}$ and $85^{\circ} \mathrm{W}$ where the $\mathrm{C}-130$ aircraft measurements were made was $13 \%$ for particle number and $28 \%$ for sulfate mass. The impact of smelter emissions is predicted to be somewhat larger in the free troposphere (not shown) than in the marine boundary layer, with number concentration being 


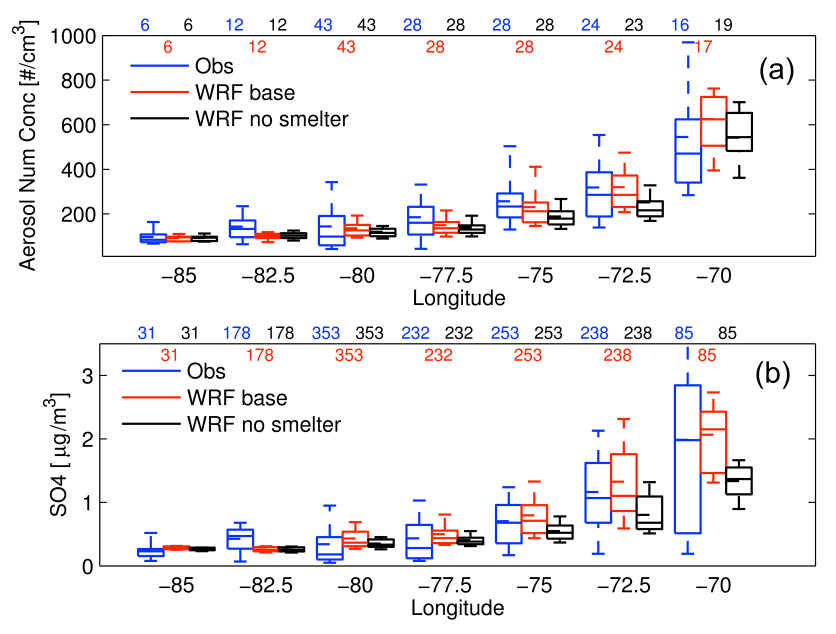

Fig. 7. (a) Comparison of aerosol number concentration between 0.12 and $3.0 \mu \mathrm{m}$ as observed from the C-130 (blue) vs. WRF-Chem model results with smelter emissions (red) and without smelter emissions (black) for the 15 October 2008 to 15 November 2008 time period. Data are gridded into 2.5 degree longitudinal zones between $22^{\circ} \mathrm{S}$ and $18^{\circ} \mathrm{S}$. The number of profiles is indicated at the top of each longitude bin. (b) Same but for measured (Allen et al., 2011) and modeled sulfate mass between $0.04 \mu \mathrm{m}$ to $0.625 \mu \mathrm{m}$, with sampling time in minutes in each longitude bin indicated at the top. For each zone, center solid (dashed) lines indicate the median (mean), and boxes indicate upper and lower quartiles with upper and lower decile whiskers.

impacted the most by $42 \%$ at $72.5^{\circ} \mathrm{W}$ and by $34 \%$, on average, between $70^{\circ} \mathrm{W}$ and $85^{\circ} \mathrm{W}$.

The WRF-CHEM-predicted particle concentrations from smelters, while not very large, are greater than the very small fraction of particles containing copper or lead detected via SEM. There are several probable reasons for this result. The larger, primary particles that serve as distinct tracers for smelting are likely diminished after several days of dilution, cloud processing and wet deposition. On the other hand, the secondary particles produced from $\mathrm{SO}_{2}$ by oxidation and condensation are smaller and may be produced farther downwind, in addition to near the source. Thus, they would be not necessarily have been detected in the Anderson et al. (1988) study, which measured particles larger than $0.4 \mu \mathrm{m}$, relatively close to the smelter itself. Possible uncertainties in model treatment include an overestimation of source emissions (Saide et al., 2012b) and a shallower than observed near-shore marine boundary layer (Saide et al., 2012a); both of which could cause higher particle number concentrations. Given these factors, the percentages contributed by smelters given in Figs. 6 and 7 can be considered to be upper limits. The electron microscopy and WRF-Chem results together indicate that different emissions, such as those from other central Chilean sources, were the major cause of the enhanced accumulation-mode particle concentrations observed near shore along $20^{\circ} \mathrm{S}$. Thus smelter emissions are a smaller source of $\mathrm{CCN}$ and influence clouds to a lesser degree than previously thought, at least along the $20^{\circ} \mathrm{S}$ latitude line. Figure 6 suggests, however, that larger effects from smelters are likely farther north, where VOCALS aircraft did not fly.

In the next section, we explore which sizes of aerosol particles are present within cloud droplets in the region, with inferences for which anthropogenic particles actually influence cloud formation by acting as $\mathrm{CCN}$.

\subsection{Aerosol size distributions}

\subsubsection{Dependence of residual particle size on droplet size}

The particle critical supersaturation, $S_{\mathrm{c}}$, is the supersaturation with respect to water that is necessary for a particle to grow from a stable deliquesced particle into a larger cloud droplet. Given the same chemical composition, Köhler theory predicts that the largest particles, which have a lower critical supersaturation, will be more active in forming droplets (Wallace and Hobbs, 1977). In addition, the larger particles are expected to form larger droplets in the initial stages of cloud formation (Twohy et al., 1989a). Subsequent in-cloud processes, such as mixing of air parcels with different histories and chemical reactions, may modify, but not completely eradicate, this size dependence (Ogren and Charlson, 1992). To explore these processes in more detail, we chose periods of relatively stable cloud properties (droplet number concentration and liquid water content) to investigate the distribution of activated droplets in stratocumuli during VOCALS flights. Increasing the counterflow rate out tip of the CVI inlet progressively increases the "cut size", rejecting smaller droplets, while retaining larger droplets. The cut size is defined as the size of droplet that is collected with $50 \%$ efficiency by the CVI, and is based on laboratory and theoretical calculations (Noone et al., 1988; Anderson et al., 1993).

Figure 8 shows the droplet residual size distribution as a function of changing droplet cut size for two VOCALS flights in the near-shore region. At the minimum droplet cut size of about $7 \mu \mathrm{m}$ diameter, a broad range of particle sizes are present within droplets, down to the $0.055 \mu \mathrm{m}$ lower limit of the optical particle counter. As smaller droplets are excluded, smaller residual particles are also excluded, and the mean particle size increases. At the largest droplet sizes, only the large particles are primarily present, with mean sizes of $0.276 \mu \mathrm{m}$ and $0.316 \mu \mathrm{m}$ for the two cases shown. These larger particles within larger droplets are consistent with simple droplet activation and growth theory, e.g., Twohy et al. (1989a). While these large droplets are relatively few in number, they are important, as they are the ones that will initiate drizzle. Additionally, they are expected to be different chemically due to differences in particle composition with size. For example, Twohy et al. (1989a) showed that larger droplets should preferentially form on sea-salt, rather than typically smaller sulfate. These alkaline droplets would 

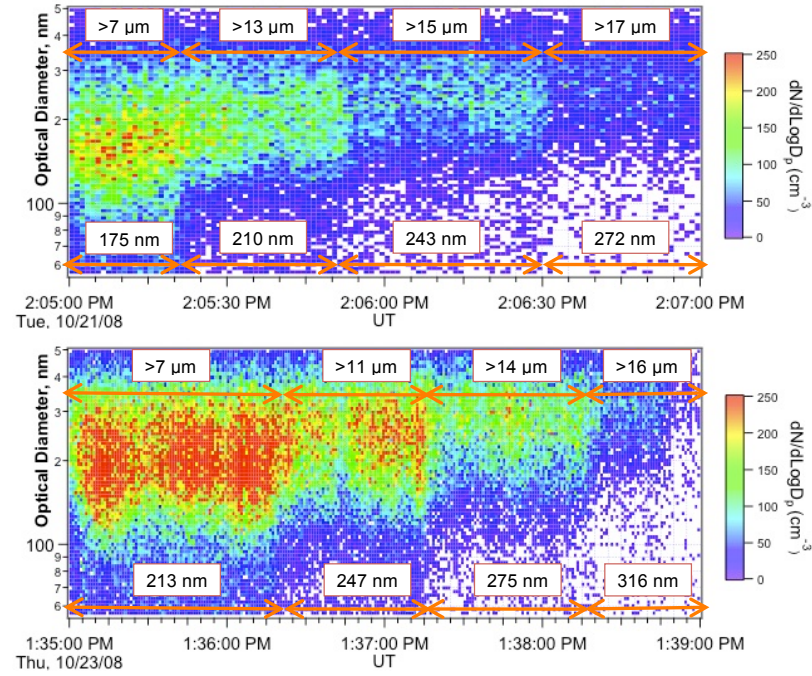

Fig. 8. Size distributions of droplet residual nuclei from droplets larger than different diameters as noted on the top of plots. Mean residual particle size is shown at bottom of plots. Top plot is from C-130 flight 3 (21 October 2008) and bottom is from flight 4 (21 October 2008).

initially contain a large fraction of available S(IV) (aqueous $\mathrm{SO}_{2}$, bisulfite and sulfite) in the cloud, which may be converted irreversibly to sulfate through aqueous-phase reactions (Hegg and Hobbs, 1979). Through this process, seasalt acts as a sink for $\mathrm{SO}_{2}$ and may limit the formation and growth of smaller sulfate aerosols (Yang et al., 2012). VOCALS electron microscopy (Fig. 4) suggests that this processing may occur in or out of cloud, with all sub-cloud samples showing evidence of some sea-salt particles being modified chemically from their expected seawater species ratios, usually with excess sulfate.

\subsubsection{Below cloud vs. droplet residual size distributions}

It is also of interest to compare the dry size distributions of below-cloud aerosol particles with those produced from evaporated droplets within the cloud, in order to evaluate which particle sizes may act as $\mathrm{CCN}$, and whether cloud processing modifies the aerosol size distribution. In-cloud periods where electron microscopy samples were obtained were matched to the closest available below-cloud period where UHSAS data were available. Samples used in this analysis were primarily, but were not limited to, those taken during flights along the $20^{\circ} \mathrm{S}$ parallel. In-cloud samples were 3-7 min in duration (about 20 to $47 \mathrm{~km}$ ) while below-cloud samples were 2-4 min in duration (about 14 to $27 \mathrm{~km}$ ). The mean time between in-cloud and below cloud samples was 18.5 $\min$ (about $125 \mathrm{~km}$ ).

Drizzle drops can break up within inlets and produce particulate artifacts downstream (Clarke et al., 1997; Weber et al., 1998; Hudson and Frisbie, 1991). For the CVI inlet, mod-

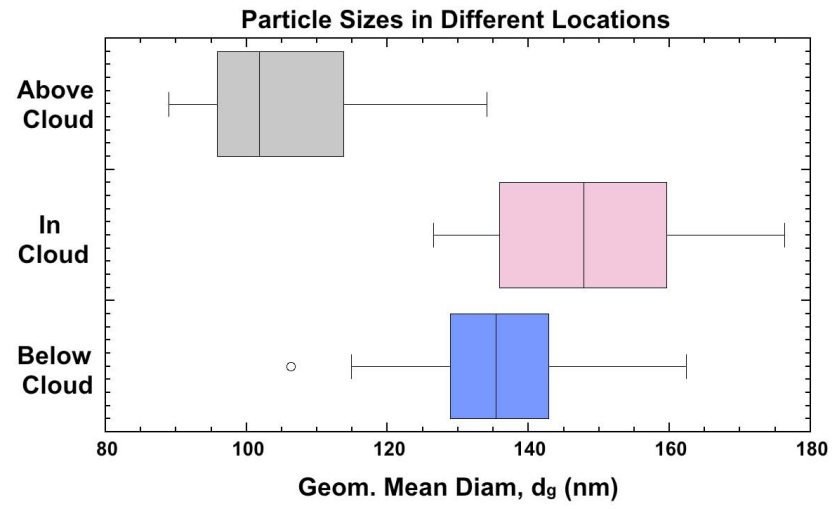

Fig. 9. Statistics of UHSAS geometric mean diameter for 20 pairs of below-cloud aerosol particles (blue) and CVI droplet residual nuclei (pink) in VOCALS clouds with drizzle $<5 \mathrm{~L}^{-1}$ and ratio of CVI total number concentration to droplet number concentration $<1$. Seventeen above-cloud samples are also shown in grey. The box limits represent the upper and lower quartiles, with the median as a vertical line. The lines extending from the left and right of each box mark the maximum and minimum values within the data set that are within the upper quartile $+(1.5 \times$ the interquartile distance $)$ or less than the lower quartile $-(1.5 \times$ the interquartile distance $)$, respectively. Outliers are marked with circles.

eling (Kulkarni and Twohy, 2011) and measurements (Twohy et al., 2003) indicate that drops larger than $\sim 100 \mu \mathrm{m}$ are prone to break up. Thus, time periods with significant drizzle were excluded from in-cloud samples, using two screening criteria that both needed to be met for samples to be accepted. First, mean drop number concentration from the 2D$\mathrm{C}$ probe was required to be $<5 \mathrm{~L}^{-1}$. The $2 \mathrm{D}-\mathrm{C}$ probe measures the $60 \mu \mathrm{m}$ to $800 \mu \mathrm{m}$ diameter drop range where the drizzle mode presides, and in VOCALS, low number concentrations were correlated with smaller drizzle drop sizes. As a second safeguard against any drizzle artifacts potentially remaining, the ratio of mean CVI total residual number to the droplet number concentration was required to be less than or equal to 1.0. The CVI number concentration was taken from the CPC downstream of the CVI inlet, while the droplet concentration was measured by the CDP (or FSSP if CDP was not operative). This screening resulted in 20 acceptable pairs of samples. The ratios of total CVI number, $N_{\mathrm{c}}$, to CDP or FSSP droplet number, $N_{\mathrm{d}}$, for these samples ranged from 0.38 to 0.96 . Low ratios could occur because in polluted cases, droplets were sometimes smaller than the minimum cut size of the CVI, and higher cut sizes were sometimes intentionally used, as discussed in the previous section.

Under a simplifying assumption of a lognormal distribution, the geometric mean diameter, $d_{\mathrm{g}}$, was calculated for each UHSAS distribution. Aggregate statistics for all samples are compared in Fig. 9. As expected, residual particles from droplets tended to be larger than below-cloud particles. $50 \%$ of the below-cloud sample $d_{\mathrm{g}}$ s fell between 0.129 and $0.143 \mu \mathrm{m}$, with a median of $0.135 \mu \mathrm{m}$, while $50 \%$ of the in- 
Table 3. Ratio of in-cloud to below-cloud particle concentration for four size distributions shown in Fig. 10.

\begin{tabular}{lcccccccccccccccc}
\hline & Diam $(\mathrm{nm})$ & 58 & 68 & 79 & 91 & 106 & 122 & 140 & 162 & 188 & 218 & 249 & 288 & 338 & 398 & $465^{*}$ \\
\hline Date Time (UTC) & & & & & & & & & & & & & & & & \\
\hline 10/18/08 13:33:32 & 0.11 & 0.15 & 0.19 & 0.24 & 0.29 & 0.29 & 0.28 & 0.25 & 0.24 & 0.28 & 0.41 & 0.54 & 0.96 & 1.20 & 0.83 \\
10/21/08 07:18:25 & 0.11 & 0.16 & 0.28 & 0.43 & 0.55 & 0.61 & 0.68 & 0.80 & 0.70 & 0.65 & 0.91 & 1.16 & 2.31 & 2.50 & 2.28 \\
10/21/08 13:14:15 & 0.09 & 0.11 & 0.15 & 0.28 & 0.36 & 0.43 & 0.54 & 0.60 & 0.63 & 0.59 & 0.68 & 0.68 & 1.00 & 0.87 & 1.20 \\
11/9/08 16:42:42 & 0.35 & 0.57 & 0.53 & 0.55 & 0.59 & 0.56 & 0.59 & 0.62 & 0.56 & 0.69 & 1.08 & 2.58 & 2.38 & 1.74 & 1.05 \\
\hline Average Ratios: & 0.16 & 0.25 & 0.29 & 0.37 & 0.45 & 0.47 & 0.52 & 0.57 & 0.53 & 0.55 & 0.77 & 1.24 & 1.66 & 1.58 & 1.34 \\
\hline
\end{tabular}

* Sizes larger than $500 \mathrm{~nm}$ not shown due to low counts and poor statistics.
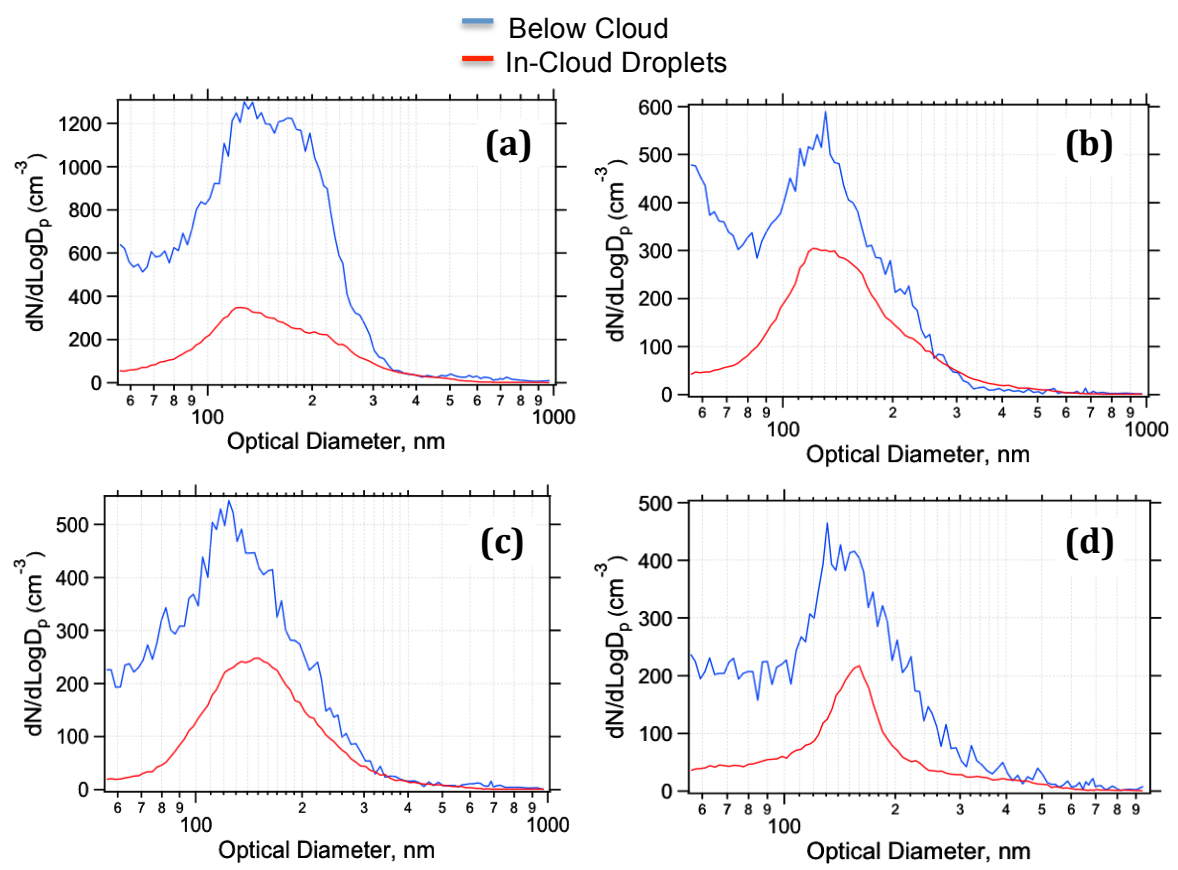

Fig. 10. UHSAS particle size distributions for four sets of paired below-cloud (blue) and in-cloud droplets (red) for CV1 samples in clouds with drizzle $<5 \mathrm{~L}^{-1}$ and ratio of CVI total number concentration to droplet number concentration between 0.72 and 0.94 . C-130 flights and in-cloud UTC times are (a) flight 2 (18 October 2008): 13:33:32-13:36:58, (b) flight 3 (21 October 2008): 07:18:25-07:24:40, (c) flight 3 (21 October 2008): 13:14:15-13:16:40, and (d) flight 11 (9 November 2008): 16:42:42-16:47:22. In-cloud distributions are less noisy than below-cloud distributions due to the enhancement factor in the CVI inlet.

cloud $d_{\mathrm{g}} \mathrm{s}$ were between 0.136 and $0.160 \mu \mathrm{m}$, with a median of $0.148 \mu \mathrm{m}$. While none of the in-cloud $d_{\mathrm{g}}$ s were smaller than $0.127 \mu \mathrm{m}$, below-cloud $d_{\mathrm{g}} \mathrm{s}$ were as small as $0.106 \mu \mathrm{m}$. Above cloud particles were even smaller than below-cloud particles, with a median $d_{\mathrm{g}}$ value of $0.102 \mu \mathrm{m}$ for samples taken shortly before or after these cloud samples.

To investigate further, below-cloud and in-cloud size distributions are plotted for four sample sets with $0.72 \leq$ $N_{\mathrm{c}} / N_{\mathrm{d}}<0.94$ (i.e., when the CVI was collecting most droplets) in Fig. 10. Plots a-d are ordered from the highest to lowest droplet concentration, representing mean $N_{\mathrm{d}}$ ranging from $292 \mathrm{~cm}^{-3}$ in Fig. 10a to $86 \mathrm{~cm}^{-3}$ for Fig. 10d. (Note that some of the extremely clean clouds sampled in VOCALS
- particularly in "pockets of open cells" - could not be sampled reliably due to the ubiquitous drizzle present.)

Most of the non-drizzling cloud distributions show greater involvement of larger particles in cloud formation, but there is considerable variability from sample to sample. This is expected based on different thermodynamic histories of each sample (see below). Additionally, the in-cloud distributions lack any clear cut-off diameter below which particles are not activated. Table 3 shows the ratio of in-cloud residual particle concentration to below-cloud particle concentration as a function of size. Particles down to the lower size limit of the UHSAS, $0.055 \mu \mathrm{m}$, are involved in cloud formation, although in smaller percentages relative to the available ambient aerosol than larger particles are. Also, the total residual 
numbers measured with the CPC indicate that some droplet residuals are even smaller than $0.055 \mu \mathrm{m}$ in size. This is important, as it indicates at least some of the cloud nuclei are coming not from the accumulation mode but from smaller particles, which may have different sources and compositions. Analyses that assume only the larger, lower $S_{\mathrm{c}}$ particles influence $\mathrm{CCN}$ concentrations (and thereby droplet number, size, drizzle concentration and radiative properties) may be incorrect. Table 3 also reveals some enhancement of particles larger than about $270 \mathrm{~nm}$ in two of the four in-cloud samples relative to their corresponding below-cloud distribution. This requires further study, but possible reasons are coalescence or in-cloud chemical reactions, both of which can add solute material to droplets.

The ability of small particles to form droplets has been observed by others; for example (Ostrom et al., 2000) found many particles smaller than $0.1 \mu \mathrm{m}$ in diameter in stratocumulus off the coast of California. This phenomenon may be due to a number of factors. First, droplets with a range of histories are sampled within a single in-cloud sample considered here, which comprises many horizontal $\mathrm{km}$ of cloud elements containing both updrafts and downdrafts. Probability plots for measured $1 \mathrm{~Hz}$ in-cloud vertical velocities during the four non-drizzling time periods are shown in Fig. 11. Each sample is a mixture of cloudy air with a wide range of vertical velocity histories. Note that vertical velocity may be positive at $50 \%$ probability (Nicholls, 1989). The probability plot format shows that for the four samples, about 10 to $40 \%$ of the vertical velocities are $>0.5 \mathrm{~m} \mathrm{~s}^{-1}$ and about $1-10 \%$ are $>1 \mathrm{~m} \mathrm{~s}^{-1}$. At $1 \mathrm{~m} \mathrm{~s}^{-1}$, supersaturations $(S)$ of $\sim 0.9 \%$ can be achieved in a low-aerosol environment and $S \sim 0.4 \%$ can be reached in a high-aerosol environment (Chuang, 2006). These values correspond to critical diameters as small as about $0.025 \mu \mathrm{m}$ to $0.045 \mu \mathrm{m}$, respectively, for sodium chloride particles and slightly larger sizes for ammonium sulfate (Hudson, 2007). The smaller size may be more likely to be activated in cleaner clouds offshore, where higher supersaturations are reached for two reasons: there are fewer available cloud condensation nuclei on which water can condense, and more variable and sometimes stronger updrafts due to stronger dynamical forcing (Bretherton et al., 2010). Higher updraft velocities are correlated with larger droplet concentrations in stratocumulus (Leaitch et al., 1996; Snider and Brenguier, 2000), presumably due to the activation of $\mathrm{CCN}$ with higher critical supersaturations, which are usually smaller in size.

A second factor is that in downdrafts and regions of entraining dryer air near cloud top, particles of various sizes can be released from droplets through evaporation. This may reduce the droplet number concentration; indeed, Leaitch et al. (1996) found that the mean droplet concentration in marine stratus was only about half the maximum droplet concentration for each in-cloud flight leg. The effect of mixing and subsequent evaporation on the residual size distribution will vary depending on whether the mixing is homogeneous, where small droplets evaporate completely, or inhomogeneous, which seems to be common (Twohy and Hudson, 1995; Lu et al., 2011). In the extreme inhomogeneous case, the parcel is essentially diluted, with a decrease in droplet concentration, but with no change in the percentage of large and small droplets. This could result in a decrease in residual particles across all sizes, while retaining the small ones, such as is seen to some extent in Fig. 10. The net effect on the residual size distribution is similar to that expected from the mixing of particles with different histories that occurs during sampling, as discussed above.

Entrainment of above-cloud air may not only evaporate existing droplets, but may be a source of new CCN to the stratocumulus cloud layer (Clarke and Kapustin, 2002). Since particles above cloud tended to be smaller than below cloud in the VOCALS region (Allen et al., 2011), this process could also be a source of additional small particles in the CVI residuals (see also modeling results, Sect. 3.3.3).

Other factors that could influence the shape of the CVI residual size distribution include differences in $\mathrm{CCN}$ chemistry, in-cloud chemical reactions (sulfate and organic aerosol production), and coalescence. Sea-salt particles are expected to be better $\mathrm{CCN}$ than the same sized sulfate particles, and organic material may influence droplet growth. However, the modeling discussed below shows that small particles can be present within droplets even without any variation in CCN properties. In-cloud chemical reactions (Hegg and Hobbs, 1979) may be active in the VOCALS region (Benedict et al., 2012), but would be expected to enhance the large residual particle population at the expense of the small ones (Feingold and Kreidenweis, 2002). Thus, varying CCN chemistry or in-cloud chemical reactions are unlikely to explain our results. Coalescence, however, could create a relative enhancement of small residual particles by removing larger particles from the cloud, a process explored further through modeling, as described below.

\subsubsection{Results of 3-D LCM/LES model with particle tracking}

For comparison with the in-cloud size distribution measurements, a Lagrangian cloud model was used to simulate particles involved in cloud nucleation, coalescence and precipitation removal in the VOCALS stratocumulus regime. Initial conditions for the Lagrangian cloud model were derived from British BAE-146 measurements along the $20^{\circ} \mathrm{S}$ line during VOCALS on 13 November 2008 at 11:08:0011:28:00 and 11:47:00-12:02:00 UTC. These two periods showed contrasting droplet concentrations in cloud and had available information about the aerosol distribution below the cloud, as well as air temperature, humidity, velocity, and radiative fluxes. The "HIGH" case at about $73^{\circ} \mathrm{W}$ had a mean cloud droplet concentration of $250 \mathrm{~cm}^{-3}$, while the "LOW" case at about $77^{\circ} \mathrm{W}$ had a droplet concentration of $65 \mathrm{~cm}^{-3}$. The initial aerosol distributions were assumed 


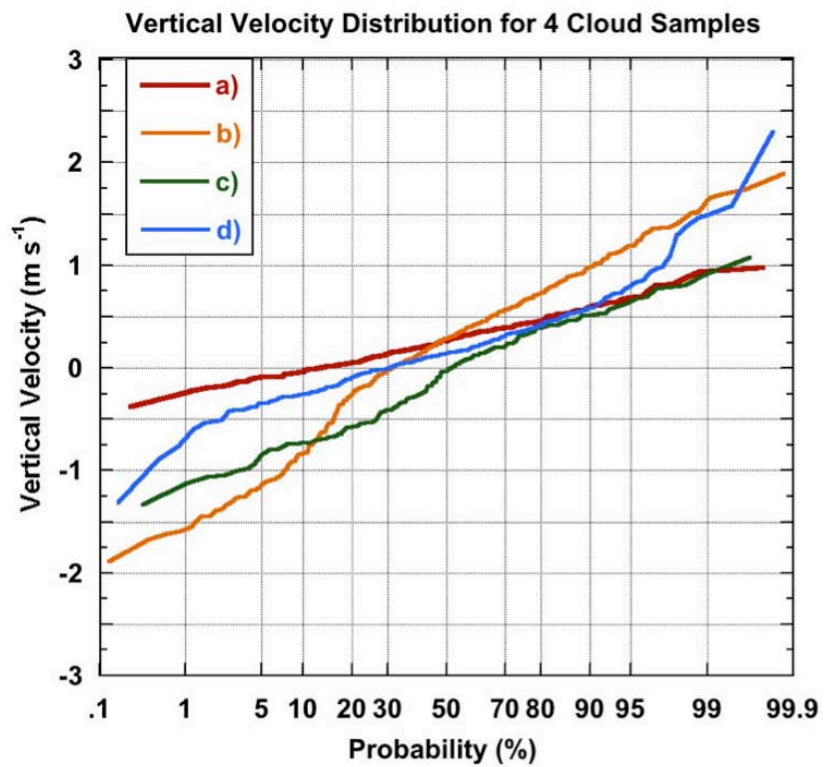

Fig. 11. Probability plot of vertical velocity $(1 \mathrm{~Hz})$ measured along the flight track for in-cloud samples (a) through (d) shown in Fig. 10.

to be bimodal and composed of ammonium sulfate. In addition to the below-cloud aerosol distribution, above cloud and the ocean surface were also potential sources of particles. 3-D simulations were run for this paper, with the horizontal velocity specified as $(u, v)=\left(-1,1 \mathrm{~m} \mathrm{~s}^{-1}\right)$ for HIGH and $\left(-3,4 \mathrm{~m} \mathrm{~s}^{-1}\right)$ for the LOW. Longwave radiative forcing was based on the Stevens et al. (2005a) representation, with parameters fitted to better reproduce observed radiative fluxes with the following tuning parameters: $F_{0}=$ $115 \mathrm{~W} \mathrm{~m}^{-2}, F_{1}=63 \mathrm{~W} \mathrm{~m}^{-2}, \kappa=91 \mathrm{~m}^{2} \mathrm{~kg}^{-1}$ for HIGH and $F_{0}=81 \mathrm{~W} \mathrm{~m}^{-2}, F_{1}=45 \mathrm{~W} \mathrm{~m}^{-2}, \kappa=73 \mathrm{~m}^{2} \mathrm{~kg}^{-1}$ for LOW. Eight hours of cloud evolution were simulated, with spinup in the model assumed to be complete after two hours. The coalescence process is active from the beginning of the third hour, and in subsequent hours, the processes that may be important in real clouds can be examined. We note, however, that the large-scale subsidence and shortwave radiative forcing that can influence stratocumulus evolution are not included in these runs.

For comparison with the in-situ measurements shown in Fig. 10, the modeled size distributions of particles larger than $0.055 \mu \mathrm{m}$ are shown in Fig. 12 for the two model cases, after two hours and eight hours of model simulation time. As in Fig. 10, the aerosol distribution below the cloud is shown with the blue line and aerosol particles within droplets (diameter $>8 \mu \mathrm{m}$ ) is the red line. The complete aerosol distribution (interstitial plus within droplets) in the cloud layer is shown as the green line. The below-cloud aerosol distributions used in the model, based on BAE-146 measurements, are slightly different from those observed on the C-130 for
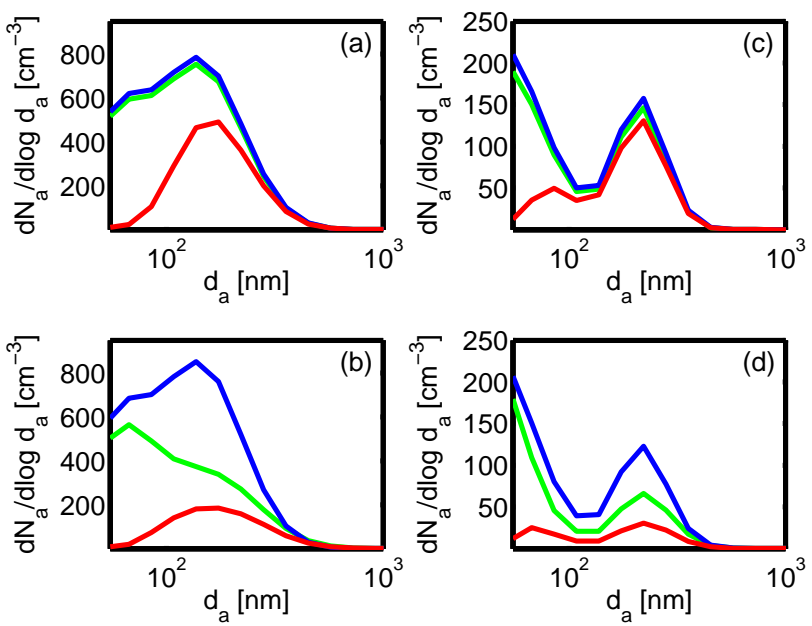

Fig. 12. Particles larger than $0.055 \mu \mathrm{m}$ for HIGH (a, b) and LOW (c, d) Lagrangian cloud model cases after $2 \mathrm{~h}$ (top) and $8 \mathrm{~h}$ (bottom) of run time. Analogous to Fig. 10, the blue line shows the aerosol size distribution below the cloud, averaged between $100-350 \mathrm{~m}$ in height, while the red line represents the particles only present within droplets larger than $8 \mu \mathrm{m}$ in size. The green line shows all particles within the cloud layer, including both interstitial and in-cloud particles. In-cloud was defined as points with $q_{\mathrm{c}}>10^{-3} \mathrm{~g} \mathrm{~kg}^{-1}$.

the periods shown in Fig. 10. Relative to the below-cloud distributions, however, the modeled in-cloud distributions are similar in shape to the observed distributions. In both cases, while larger particles tend to be more active in cloud formation, no sharp activation is observed at a single particle size. This wide range of within-droplet particle sizes occurs without invoking any difference in particle chemistry or hygroscopicity. Rather, it is likely due to the different thermodynamic histories of air parcels and the influence of coalescence, as described below. Results for the HIGH (panels a and b) and LOW (panels $c$ and d) cloud droplet cases are similar. However, for the LOW case because of the fewer particles and higher in-cloud supersaturations, there is greater involvement of smaller particles in cloud droplet nucleation.

Some of the in-cloud CVI data (Fig. 10) look like the twohour model simulations (after spin-up is complete), while others look more like the later simulations, with a broader, flatter appearance. The greater horizontal extent and therefore variable thermodynamic history for the CVI in-situ samples is one explanation for this; for example, the model never predicted vertical velocities larger than $1 \mathrm{~m} \mathrm{~s}^{-1}$, while these were sometimes observed in the C-130 in-situ measurements (Fig. 11). Additionally, an active collision/coalescence and drizzle process occurring prior to sampling the actual clouds could produce this effect.

Over time, the difference between the initial below-cloud aerosol distribution and the aerosol distribution inside the droplets increases for both model cases. This difference is partially due to a change in the total particle distribution 

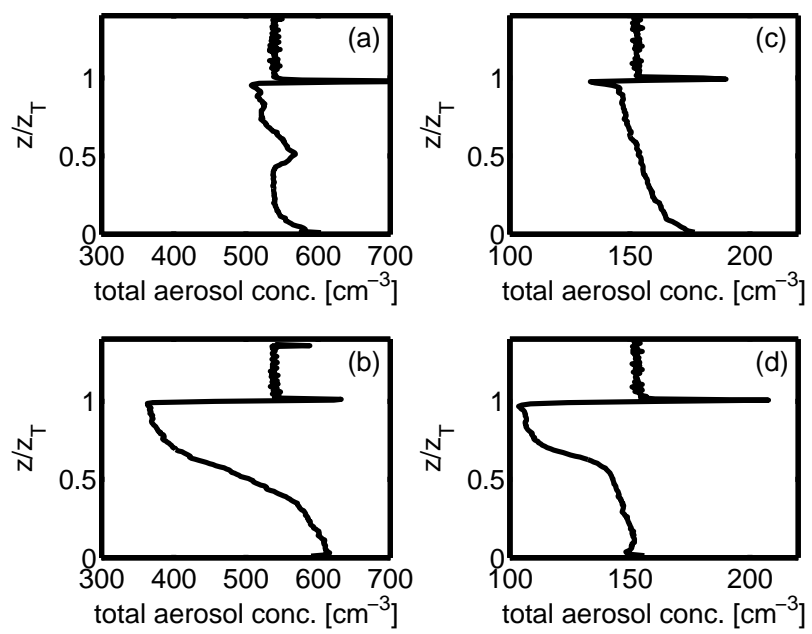

Fig. 13. Total aerosol concentration (ambient, interstitial and within droplets) predicted by the LCM after $2 \mathrm{~h}$ (top, a and c) and $8 \mathrm{~h}$ (bottom, $\mathbf{b}$ and $\mathbf{d}$ ), as a function of height, scaled to the top of the cloud. HIGH aerosol case results are on the left and LOW aerosol case results are on the right.

within the cloud as a result of aerosol processing by coalescence. The coalescence process moves many particles initially in the $\sim 0.1$ to $0.3 \mu \mathrm{m}$ size range to a few larger particles, which eventually may be removed as drizzle. Figure 13 shows the vertical profiles of total aerosol (activated and unactivated) predicted at $8 \mathrm{~h}$ for the HIGH and LOW simulation. While initially the aerosol profiles are uniform throughout the boundary layer, over time, the aerosol particles just below and in the cloud layer are depleted relative to the nearsurface layer. This is due to coalescence and drizzle removing particles from the cloud faster than they are replenished from the surface or from above the cloud.

We also investigated where the model predicted aerosol particles within cloud droplets to originate for the two simulations. The major source of the particle number concentration within cloud droplets at all times was particles originating below the cloud. After $8 \mathrm{~h}$ of simulation, about $20 \%$ of the aerosol within droplets could be attributed to other sources: for the HIGH simulation, this was primarily particles entrained from above the cloud, while for the LOW simulation, it was primarily particles generated from the ocean surface. Thus particle entrainment from above and particle generation from below may be small, but non-negligible sources of $\mathrm{CCN}$.

\subsection{Cloud thickness, liquid water path and potential radiative impact}

In earlier sections, we have shown that the enhanced particles in the VOCALS near-shore region are related to higher cloud droplet concentrations and smaller droplet effective radii. However, cloud liquid water path, as well as droplet effective radius, determine cloud optical thickness $\tau$ through the following approximation (George and Wood, 2010):

$\tau \approx \frac{1.8 \mathrm{LWP}}{r_{\mathrm{e}} \rho_{\mathrm{W}}}$

Cloud optical thickness, in turn, determines visible cloud albedo or reflectance. Thus, the enhanced droplet number concentration and reduced droplet size observed in the VOCALS near-shore region would be expected to produce more reflective clouds if LWP stayed constant (or increased) relative to an unperturbed stratocumulus region. This is explored further in the following sections.

\subsubsection{Liquid water path and thickness}

LWP was derived for the $20^{\circ} \mathrm{S}$ missions from the G-band Vapor Radiometer (GVR) (Zuidema et al., 2012), supplemented by adiabatic LWP derived from the on-board radar (Wang et al., 2012) when GVR data were not available. The upward-looking radar and lidar (Wang et al., 2012) were used to estimate cloud thickness during the sub-cloud flight legs. While quite variable, both cloud thickness and the closely related LWP were generally smaller near shore for the VOCALS time period (Fig. 14a), with both being significantly correlated with distance from shore (Table 2). This change in cloud physical properties is observed in satellite data also (Painemal and Zuidema, 2010) and is probably related to the large scale meteorology; for example, the increased subsidence and thinner boundary layer near shore (Wyant et al., 2010; George and Wood, 2010). Some modeling studies have shown that higher aerosol concentrations may lead to smaller liquid water paths through enhanced entrainment of dry air (Ackerman et al., 2004) or reduced drizzle-driven turbulence and smaller moisture flux from the ocean surface (Jiang et al., 2002). However, during a series of VOCALS measurements at a fixed near-shore location $\left(20^{\circ} \mathrm{S}, 72^{\circ} \mathrm{W}\right)$, Zheng et al. (2011) found that LWP actually was positively correlated with aerosol concentration for a well-mixed boundary layer. The response of LWP to aerosol particles may even depend on the cloud base height (Wood, 2007).

Regardless of the still poorly understood cause, the generally thinner characteristic of the near-shore cloud field is very important in interpreting satellite measurements, which show small effective radii near shore. Due to condensational growth, droplet size increases with depth throughout the cloud layer. As a result, clouds with smaller thicknesses and liquid water paths will, for a given droplet concentration, have smaller droplets. Returning to the VOCALS hypothesis presented earlier, it seems that the small effective radius near shore is not only due to the presence of anthropogenic pollutants increasing droplet number concentration, but also due to the large-scale forcing that causes clouds to be thinner near shore.

The relative contributions of increasing droplet concentration and decreasing cloud thickness in modifying the $r_{\mathrm{e}}$ of 

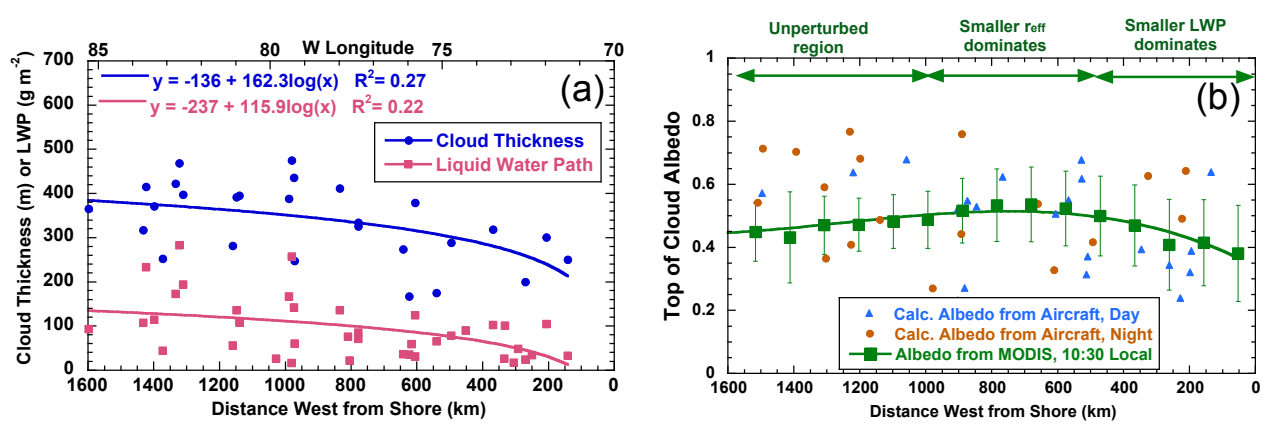

Fig. 14. (a) Cloud geometric thickness and liquid water path (LWP) as a function of distance west from shore along $20^{\circ} \mathrm{S}$. Thickness is from the in-situ radar and lidar, while LWP uses both GVR and radar data. Uncertainty is estimated to be $30 \mathrm{~m}$ for geometric thickness (D. Leon, personal communication, 2012) and $20 \mathrm{~g} \mathrm{~m}^{-2}$ for LWP (Zuidema et al., 2012). (b) Top of cloud albedo vs. distance from shore calculated as described in the text (using 10:30 local values for solar zenith angle). Circles are values derived from onboard remote sensors during daytime (purple) and night-time (blue) C-130 flight segments, while green squares are derived from the MODIS 10:30 local overpass averaged over the entire VOCALS 31-day time period. Vertical bars represent one sigma variability in the MODIS data. Since in-cloud data only was used, cloud albedos here are higher than net albedos in partly cloudy regions.

near-shore clouds can be estimated as follows. Since the VOCALS clouds tended to be quasi-adiabatic (Zuidema et al., 2012), changes in $r_{\mathrm{e}}$ can be related to changes in the height above cloud base, $h$, and droplet number concentration $N_{\mathrm{d}}$ through Eq. (11) of Brenguier et al. (2000):

$r_{\mathrm{e}} \propto\left(\frac{h}{N_{\mathrm{d}}}\right)^{1 / 3}$

Holding the near-shore cloud thickness constant at $200 \mathrm{~m}$ (Fig. 14a) while changing $N_{\mathrm{d}}$ from the unperturbed value of $80 \mathrm{~cm}^{-3}$ to the polluted value of $250 \mathrm{~cm}^{-3}$ (Fig. 1c) yields a decrease in $r_{\mathrm{e}}$ of $32 \%$. Holding the near-shore $N_{\mathrm{d}}$ constant while changing the cloud thickness from $400 \mathrm{~m}$ to $200 \mathrm{~m}$ yields an $r_{\mathrm{e}}$ decrease of $21 \%$. Thus about $60 \%$ of the net decrease in $r_{\mathrm{e}}$ can be attributed to the change in $N_{\mathrm{d}}$ (a microphysical change due to enhanced pollution), while about $40 \%$ is due to the smaller cloud thickness near shore, more likely a macroscale effect.

\subsubsection{Cloud albedo and factors influencing it}

Top-of-cloud albedo, $A_{\mathrm{TOC}}$, was calculated for both the insitu and MODIS satellite data as a function of $\tau$ (Eq. 1), using the delta-Eddington approximation following Eq. (37) of King and Harshvardhan (1986). Since $r_{\mathrm{e}}$ measured from the CDP during in-situ cloud legs is dependent on the sampling height and does not necessarily reflect the near-cloud-top value measured by satellite, $r_{\mathrm{e}}$ for the in-situ albedo calculations was derived from the aircraft-measured droplet number concentration and LWP, as described in George and Wood (2010). MODIS cloud albedo was calculated using LWP and $r_{\mathrm{e}}$ derived from the 10:30 a.m. local satellite overpass for one-degree increments along $20^{\circ} \mathrm{S}$ between 15 October to 15 November 2008, and averaged for these dates. The solar zenith angle at 10:30 local time was used for both the satel- lite and in-situ albedo calculations. Typical levels of absorbing black carbon $\left(<50 \mathrm{ng} \mathrm{m}^{-3}\right)$ measured from the C-130 in VOCALS (Shank et al., 2012) should have a negligible effect on cloud albedo (Twohy et al., 1989b).

Figure 14b shows cloud albedos derived from the two techniques (in-situ and remote sensing). For the in-situ data, samples between 08:30 and 20:30 local time are plotted separately from 20:30 to 08:30 local time, since LWPs tend to be lower during daytime hours due to solar insolation (Wood et al., 2002). Albedo values were calculated during nighttime hours for completeness, as most of the data far offshore were collected at night. Results for satellite and in-situ data are similar in magnitude, particularly for near-shore clouds. The far-offshore albedos from the in-situ data are larger than those from MODIS at 10:30 local, a result of the large LWPs that tend to occur during nighttime hours. Additionally, the in-situ data points exhibit strong variability with a slight increasing trend offshore that is not statistically significant.

Albedos derived from the MODIS satellite data are more statistically robust because the daily data are averaged over the entire month-long intensive observation period, as well as over one-degree increments in both latitude and longitude, while the aircraft data represent single flight legs on one day, in one dimension. Using Fig. 14b and relying on the satellite data for a more representative data set, relative to apparently unperturbed clouds $1000 \mathrm{~km}$ or farther offshore, MODIS cloud albedos (open squares) increase slightly between about 500 and $1000 \mathrm{~km}$ from shore. This corresponds to the region that Allen et al. (2011) named the "transitional" zone, between about $75^{\circ} \mathrm{W}$ and $80^{\circ} \mathrm{W}$. Note in Fig. $1 \mathrm{~b}$ and $\mathrm{c}$ that droplet concentration is enhanced and droplet size is decreased in this region relative to the unperturbed clouds offshore. However, nearer shore, albedo decreases again substantially. Since droplet size is definitely smaller near shore (Fig. 1c), this decrease in near-shore albedo must be due not 
to a droplet size effect, but to the decrease in cloud thickness and LWP which reduces the cloud optical thickness near shore (Eq. 1). The net effect of these factors is that cloud albedo actually tends to be smaller near shore, with a slight enhancement offshore where aerosol particles impact the droplet concentration, but clouds are still relatively thick.

The observation that an increase in albedo is not observed near shore relative to offshore does not mean, however, that present day pollutants are not changing cloud properties relative to pre-industrial values. If the pre-industrial droplet concentrations throughout the region were similar to those measured in unperturbed air offshore, a significantly smaller effective radius and lower cloud albedo would have existed at that time, assuming liquid water paths were similar to the present day (George and Wood, 2010). Thus, anthropogenic pollutants being produced today still may be producing a significant cloud brightening effect. The complex factors influencing cloud liquid water path (mesoscale variability, proximity to land, and even aerosol concentration), however, make this theory difficult to validate.

\section{Summary and conclusions}

Aerosol particle number concentrations were observed to increase near the Chilean shoreline in the southeast Pacific due to pollution from continental sources. The effect extends $\sim 800$ to $1000 \mathrm{~km}$ offshore. The additional particles are mainly sulfates from anthropogenic sources, but various other particle types are present in small percentages. Sulfate internally mixed with sea-salt also occurs in and out of cloud. Smelters are apparently a smaller particle source to the VOCALS study region along $20^{\circ} \mathrm{S}$ than previously supposed. Higher particle concentrations near shore were associated with more, smaller cloud droplets, and with less liquid water in the drizzle drop size range.

Other new results are that a variety of particle sizes (down to at least $0.055 \mu \mathrm{m}$ in diameter), not just the largest ones, can act as cloud nuclei in stratocumulus clouds in the southeast Pacific. This is likely due to the high supersaturations experienced by some cloud parcels, and to mixing occurring in the atmosphere and during sampling. The smaller nuclei are often associated with smaller droplets. Increased pollutants result in higher droplet number concentrations and contribute to the smaller droplet effective radii near shore. Here we return to the VOCALS hypothesis presented in the Introduction: "The small effective radii measured from space over the SEP are primarily controlled by anthropogenic, rather than natural, aerosol production". In fact, droplet effective radii are smaller near shore, but this is a combined effect of anthropogenic aerosol increasing droplet number concentration $\left(\sim 60 \%\right.$ impact on $\left.r_{\mathrm{e}}\right)$ and the physically thinner clouds present near shore $\left(\sim 40 \%\right.$ impact on $\left.r_{\mathrm{e}}\right)$. Thus, smaller droplets cannot be attributed solely to anthropogenic effects.
Based on measurements from MODIS, the net effect of changes in LWP and $r_{\mathrm{e}}$ relative to unperturbed "clean" clouds is that cloud albedo is actually lower within $\sim 300 \mathrm{~km}$ of shore. Albedo is slightly higher $500-1000 \mathrm{~km}$ offshore, in a transition zone where droplet concentration is slightly enhanced and changes in $r_{\mathrm{e}}$ apparently dominate over changes in liquid water path. Better knowledge of factors and feedbacks controlling liquid water path is critical to understanding and predicting aerosol indirect effects in stratocumulus clouds.

Acknowledgements. Work by lead author CT was primarily supported by the National Science Foundation under ATM0746685. Additionally, co-authors acknowledge the following agencies/grants. MA: NERC grant NE/F018673/1; JA: NSF grant ATM-0746671; PS and SS: NSF grant 0748012, NASA grants NNX08AL05G and NNX11AI52G, NCRR grant UL1RR024979, and Fulbright-CONICYT scholarship number 15093810. Data used to derive initial conditions for the numerical model were provided by the British Atmospheric Data Centre (BADC). The rest of the observational data used in this research were provided by NCAR/EOL under sponsorship of the National Science Foundation: http://data.eol.ucar.edu/. We would like to especially thank the National Center for Atmospheric Research C-130 flight and support crew. We also thank Jefferson Snider for PCASP calibrations and helpful discussions, Droplet Measurement Technologies for modification of the University of Colorado benchtop UHSAS instrument for operation under flight conditions, and Chris Webster at NCAR for 2D-C processing assistance. Any opinions, findings, and conclusions or recommendations expressed in this material are those of the authors and do not necessarily reflect the views of the National Science Foundation or other agencies cited.

Edited by: B. Albrecht

\section{References}

Ackerman, A. S., Toon, O. B., Stevens, D. E., Heymsfield, A. J., Ramanathan, V., and Welton, E. J.: Reduction of tropical cloudiness by soot, Science, 288, 1042-1047, 2000.

Ackerman, A. S., Toon, O. B., Stevens, D. E., and Coakley, J. A.: Enhancement of cloud cover and suppression of nocturnal drizzle in stratocumulus polluted by haze, Geophys. Res. Lett., 30, 1381, doi:10.1029/2002g1016634, 2003.

Ackerman, A. S., Kirkpatrick, M. P., Stevens, D. E., and Toon, O. B.: The impact of humidity above stratiform clouds on indirect aerosol climate forcing, Nature, 432, 1014-1017, doi:10.1038/nature03174, 2004.

Allen, G., Coe, H., Clarke, A., Bretherton, C., Wood, R., Abel, S. J., Barrett, P., Brown, P., George, R., Freitag, S., McNaughton, C., Howell, S., Shank, L., Kapustin, V., Brekhovskikh, V., Kleinman, L., Lee, Y.-N., Springston, S., Toniazzo, T., Krejci, R., Fochesatto, J., Shaw, G., Krecl, P., Brooks, B., McMeeking, G., Bower, K. N., Williams, P. I., Crosier, J., Crawford, I., Connolly, P., Allan, J. D., Covert, D., Bandy, A. R., Russell, L. M., Trembath, J., Bart, M., McQuaid, J. B., Wang, J., and Chand, D.: South East Pacific atmospheric composition and variabil- 
ity sampled along $20^{\circ} \mathrm{S}$ during VOCALS-REx, Atmos. Chem. Phys., 11, 5237-5262, doi:10.5194/acp-11-5237-2011, 2011.

Anderson, J., Moore, G., Fernando, H., and Hyde, P.: A field study of particulate emissions from major roadways in the Phoenix airshed, Arizona Dept. of Transportation, 495, 101, 2006.

Anderson, J. R., Aggett, F. J., Buseck, P. R., Germani, M. S., and Shattuck, T. W.: Chemistry of Individual Aerosol Particles from Chandler, Arizona, an Arid Urban Environment, Environ. Sci. Technol., 22, 811-818, 1988.

Anderson, J. R., Buseck, P. R., Patterson, T. L., and Arimoto, R.: Characterization of the Bermuda tropospheric aerosol by combined individual-particle and bulk-aerosol analysis, Atmos. Environ., 30, 319-338, 10.1016/1352-2310(95)00170-4, 1996.

Anderson, T. L., Charlson, R. J., and Covert, D. S.: Calibration of a counterflow virtual impactor at aerodynamic diameters from 1 to 15 micrometers, Aerosol Sci. Tech., 19, 317-329, doi:10.1080/02786829308959639, 1993.

Andrejczuk, M., Reisner, J. M., Henson, B., Dubey, M. K., and Jeffery, C. A.: The potential impacts of pollution on a nondrizzling stratus deck: Does aerosol number matter more than type?, J. Geophys. Res.-Atmos., 113, D19204, doi:10.1029/2007jd009445, 2008.

Andrejczuk, M., Grabowski, W. W., Reisner, J., and Gadian, A.: Cloud-aerosol interactions for boundary layer stratocumulus in the Lagrangian Cloud Model, J. Geophys. Res.-Atmos., 115, D22214, doi:10.1029/2010jd014248, 2010.

Baumgardner, D. and Korolev, A.: Airspeed Corrections for Optical Array Probe Sample Volumes, J. Atmos. Ocean. Tech., 14, 1224-1229, doi:10.1175/15200426(1997)014;1224:ACFOAP ¿2.0.CO;2, 1997.

Benedict, K. B., Lee, T., and Collett, J. L.: Cloud water composition over the southeastern Pacific Ocean during the VOCALS regional experiment, Atmos. Environ., 46, 104-114, doi:10.1016/j.atmosenv.2011.10.029, 2012.

Berner, A. H., Bretherton, C. S., and Wood, R.: Large-eddy simulation of mesoscale dynamics and entrainment around a pocket of open cells observed in VOCALS-REx RF06, Atmos. Chem. Phys., 11, 10525-10540, doi:10.5194/acp-11-10525-2011, 2011.

Brenguier, J. L., Pawlowska, H., Schuller, L., Preusker, R., Fischer, J., and Fouquart, Y.: Radiative properties of boundary layer clouds: Droplet effective radius versus number concentration, J. Atmos. Sci., 57, 803-821, doi:10.1175/15200469(2000)057;0803:rpoblc ¿2.0.co;2, 2000.

Bretherton, C. S., Wood, R., George, R. C., Leon, D., Allen, G., and Zheng, X.: Southeast Pacific stratocumulus clouds, precipitation and boundary layer structure sampled along $20^{\circ} \mathrm{S}$ during VOCALS-REx, Atmos. Chem. Phys., 10, 10639-10654, doi:10.5194/acp-10-10639-2010, 2010.

Chapman, E. G., Gustafson Jr., W. I., Easter, R. C., Barnard, J. C., Ghan, S. J., Pekour, M. S., and Fast, J. D.: Coupling aerosolcloud-radiative processes in the WRF-Chem model: Investigating the radiative impact of elevated point sources, Atmos. Chem. Phys., 9, 945-964, doi:10.5194/acp-9-945-2009, 2009.

Chen, Y.-C., Christensen, M. W., Xue, L., Sorooshian, A., Stephens, G. L., Rasmussen, R. M., and Seinfeld, J. H.: Occurrence of lower cloud albedo in ship tracks, Atmos. Chem. Phys., 12, 8223-8235, doi:10.5194/acp-12-8223-2012, 2012.

Chuang, P. Y.: Sensitivity of cloud condensation nuclei activation processes to kinetic parameters, J. Geophys. Res., 111, D09201, doi:10.1029/2005jd006529, 2006.

Clarke, A. D. and Kapustin, V. N.: A pacific aerosol survey. Part I: A decade of data on particle production, transport, evolution, and mixing in the troposphere, J. Atmos. Sci., 59, 363-382, doi:10.1175/1520-0469(2002)059;0363:apaspi $; 2.0 . c 0 ; 2,2002$.

Clarke, A. D., Uehara, T., and Porter, J. N.: Atmospheric nuclei and related aerosol fields over the Atlantic: Clean subsiding air and continental pollution during ASTEX, J. Geophys. Res., 102, 25281-25292, 1997.

Comstock, K. K., Yuter, S. E., Wood, R., and Bretherton, C. S.: The three-dimensional structure and kinematics of drizzling stratocumulus, Mon. Weather Rev., 135, 3767-3784, doi:10.1175/2007mwr1944.1, 2007.

Fahey, K. M. and Pandis, S. N.: Optimizing model performance: variable size resolution in cloud chemistry modeling, Atmos. Environ., 35, 4471-4478, doi:10.1016/s1352-2310(01)00224-2, 2001.

Fast, J. D. and Easter, R. C.: A Lagrangian Particle Dispersion Model Compatible with WRF, 7th Annual WRF User's Workshop, Boulder, CO, 19-22 June 2006, 2006.

Fast, J. D., Gustafson, W. I., Easter, R. C., Zaveri, R. A., Barnard, J. C., Chapman, E. G., Grell, G. A., and Peckham, S. E.: Evolution of ozone, particulates, and aerosol direct radiative forcing in the vicinity of Houston using a fully coupled meteorology-chemistry-aerosol model, J. Geophys. Res.-Atmos., 111, D21305, doi:10.1029/2005jd006721, 2006.

Feingold, G. and Kreidenweis, S. M.: Cloud processing of aerosol as modeled by a large eddy simulation with coupled microphysics and aqueous chemistry, J. Geophys. Res.-Atmos., 107, 4687, doi:10.1029/2002jd002054, 2002.

George, R. C. and Wood, R.: Subseasonal variability of low cloud radiative properties over the southeast Pacific Ocean, Atmos. Chem. Phys., 10, 4047-4063, doi:10.5194/acp-10-4047-2010, 2010.

Grell, G. A., Peckham, S. E., Schmitz, R., McKeen, S. A., Frost, G., Skamarock, W. C., and Eder, B.: Fully coupled "online" chemistry within the WRF model, Atmos. Environ., 39, 6957-6975, doi:10.1016/j.atmosenv.2005.04.027, 2005.

Hartmann, D. L., Ockertbell, M. E., and Michelsen, M. L.: The effect of cloud type on earths energy-balance global analysis, J. Climate, 5, 1281-1304, doi:10.1175/15200442(1992)005;1281:teocto 2 2.0.co;2, 1992.

Hawkins, L. N., Russell, L. M., Covert, D. S., Quinn, P. K., and Bates, T. S.: Carboxylic acids, sulfates, and organosulfates in processed continental organic aerosol over the southeast Pacific Ocean during VOCALS-REx 2008, J. Geophys. Res.-Atmos., 115, D13201, doi:10.1029/2009jd013276, 2010.

Hegg, D. A. and Hobbs, P. V.: The homogeneous oxidation of sulfur dioxide in cloud droplets, Atmos. Environ., 13, 981-987, 1979.

Hegg, D. A., Covert, D. S., Jonsson, H. H., and Woods, R. K.: A simple relationship between cloud drop number concentration and precursor aerosol concentration for the regions of Earth's large marine stratocumulus decks, Atmos. Chem. Phys., 12, 1229-1238, doi:10.5194/acp-12-1229-2012, 2012.

Hudson, J. G.: Variability of the relationship between particle size and cloud-nucleating ability, Geophys. Res. Lett., 34, L08801, doi:10.1029/2006g1028850, 2007.

Hudson, J. G. and Frisbie, P. R.: Cloud condensation nuclei near marine stratus, J. Geophys. Res.-Atmos., 96, 20795-20808, 
doi:10.1029/91jd02212, 1991.

Huneeus, N., Gallardo, L., and Rutllant, J. A.: Offshore transport episodes of anthropogenic sulfur in northern Chile: Potential impact on the stratocumulus cloud deck, Geophys. Res. Lett., 33, L19819, doi:10.1029/2006g1026921, 2006.

Jiang, H. L., Feingold, G., and Cotton, W. R.: Simulations of aerosol-cloud-dynamical feedbacks resulting from entrainment of aerosol into the marine boundary layer during the Atlantic Stratocumulus Transition Experiment, J. Geophys. Res.-Atmos., 107, 4813, doi:10.1029/2001jd001502, 2002.

King, M. D. and Harshvardhan: Comparative Accuracy of Selected Multiple-Scattering Approximations, J. Atmos. Sci., 43, 784801, 1986.

King, N. J., Bower, K. N., Crosier, J., and Crawford, I.: Evaluating MODIS cloud retrievals with in situ observations from VOCALS-REx, Atmos. Chem. Phys., 13, 191-209, doi:10.5194/acp-13-191-2013, 2013.

Kleinman, L. I., Daum, P. H., Lee, Y.-N., Lewis, E. R., Sedlacek III, A. J., Senum, G. I., Springston, S. R., Wang, J., Hubbe, J., Jayne, J., Min, Q., Yum, S. S., and Allen, G.: Aerosol concentration and size distribution measured below, in, and above cloud from the DOE G-1 during VOCALS-REx, Atmos. Chem. Phys., 12, 207223, doi:10.5194/acp-12-207-2012, 2012.

Korolev, A.: Reconstruction of the Sizes of Spherical Particles from Their Shadow Images. Part I: Theoretical Considerations, J. Atmos. Ocean. Tech., 24, 376-389, doi:10.1175/JTECH1980.1, 2007.

Kulkarni, G. and Twohy, C.: Computational fluid dynamics studies to understand ice crystal and liquid droplet breakup within an airborne counterflow virtual impactor, Thirtieth Annual Conference, American Association for Aerosol Research,, Orlando, FL, 3-7 October 2011, 2011.

Lance, S., Brock, C. A., Rogers, D., and Gordon, J. A.: Water droplet calibration of the Cloud Droplet Probe (CDP) and inflight performance in liquid, ice and mixed-phase clouds during ARCPAC, Atmos. Meas. Tech., 3, 1683-1706, doi:10.5194/amt3-1683-2010, 2010.

Leaitch, W. R., Banic, C. M., Isaac, G. A., Couture, M. D., Liu, P. S. K., Gultepe, I., Li, S. M., Kleinman, L., Daum, P. H., and MacPherson, J. I.: Physical and chemical observations in marine stratus during the 1993 North Atlantic Regional Experiment: Factors controlling cloud droplet number concentrations, J. Geophys. Res.-Atmos., 101, 29123-29135, doi:10.1029/96jd01228, 1996.

Leaitch, W. R., Lohmann, U., Russell, L. M., Garrett, T., Shantz, N. C., Toom-Sauntry, D., Strapp, J. W., Hayden, K. L., Marshall, J., Wolde, M., Worsnop, D. R., and Jayne, J. T.: Cloud albedo increase from carbonaceous aerosol, Atmos. Chem. Phys., 10, 7669-7684, doi:10.5194/acp-10-7669-2010, 2010.

Lee, S. S., Penner, J. E., and Saleeby, S. M.: Aerosol effects on liquid-water path of thin stratocumulus clouds, J. Geophys. Res.Atmos., 114, D07204, doi:10.1029/2008jd010513, 2009.

Lu, C. S., Liu, Y. G., and Niu, S. J.: Examination of turbulent entrainment-mixing mechanisms using a combined approach, J. Geophys. Res.-Atmos., 116, D20207, doi:10.1029/2011jd015944, 2011.

Marshak, A., Wen, G., Coakley, J. A., Remer, L. A., Loeb, N. G., and Cahalan, R. F.: A simple model for the cloud adjacency effect and the apparent bluing of aerosols near clouds, J. Geophys.
Res.-Atmos., 113, D14s17, doi:10.1029/2007jd009196, 2008.

Nicholls, S.: The structure of radiatively driven convection in stratocumulus, Q. J. Roy. Meteor. Soc., 115, 487-511, doi:10.1002/qj.49711548704, 1989.

Noone, K. J., Ogren, J. A., Heintzenberg, J., Charlson, R. J., and Covert, D. S.: Design and calibration of a counterflow virtual impactor for sampling of atmospheric fog and cloud droplets, Aerosol Sci. Tech., 8, 235-244, doi:10.1080/02786828808959186, 1988.

Ogren, J. A. and Charlson, R. J.: Implications for models and measurements of chemical inhomogeneities among cloud droplets, Tellus B, 44B, 208-225, 1992.

Ostrom, E., Noone, K. J., and Pockalny, R. A.: Cloud droplet residual particle microphysics in marine stratocumulus clouds observed during the Monterey Area Ship Track experiment, J. Atmos. Sci., 57, 2671-2683, doi:10.1175/15200469(2000)057;2671:cdrpmi $; 2.0 . c 0 ; 2,2000$.

Painemal, D. and Zuidema, P.: Microphysical variability in southeast Pacific Stratocumulus clouds: synoptic conditions and radiative response, Atmos. Chem. Phys., 10, 6255-6269, doi:10.5194/acp-10-6255-2010, 2010.

Quaas, J., Stevens, B., Stier, P., and Lohmann, U.: Interpreting the cloud cover - aerosol optical depth relationship found in satellite data using a general circulation model, Atmos. Chem. Phys., 10, 6129-6135, doi:10.5194/acp-10-6129-2010, 2010.

Reisner, J. M., Mousseau, V. A., Wyszogrodzki, A. A., and Knoll, D. A.: An implicitly balanced hurricane model with physicsbased preconditioning, Mon. Weather Rev., 133, 1003-1022, doi:10.1175/mwr2901.1, 2005.

Russell, L., Hawkins, L. N., Frossard, A. A., Quinn, P. K., and Bates, T. S.: Carbohydrate-like composition of submicron atmospheric particles and their production from ocean bubble bursting, P. Natl. Acad. Sci. USA, 107, 16652-16657, doi:10.1073/pnas.0908905107, 2010.

Saide, P. E., Spak, S. N., Carmichael, G. R., Mena-Carrasco, M. A., Yang, Q., Howell, S., Leon, D. C., Snider, J. R., Bandy, A. R., Collett, J. L., Benedict, K. B., de Szoeke, S. P., Hawkins, L. N., Allen, G., Crawford, I., Crosier, J., and Springston, S. R.: Evaluating WRF-Chem aerosol indirect effects in Southeast Pacific marine stratocumulus during VOCALS-REx, Atmos. Chem. Phys., 12, 3045-3064, doi:10.5194/acp-12-3045-2012, $2012 \mathrm{a}$.

Saide, P. E., Carmichael, G., Spak, S. N., Minnis, P., and Ayers, J. $\mathrm{K}$.: Improving aerosol distributions below clouds by assimilating satellite-retrieved cloud droplet number, P. Natl. Acad. Sci. USA, 109, 11939-11943, doi:10.1073/pnas.1205877109, 2012b.

Schüller, M., Estrada, A., and Bringezu, S.: Mapping Environmental Performance of International Raw Material Production Flows: a Comparative Case Study for the Copper Industry of Chile and Germany, Minerals and Energy, 2, 29-45, 2008.

Shank, L. M., Howell, S., Clarke, A. D., Freitag, S., Brekhovskikh, V., Kapustin, V., McNaughton, C., Campos, T., and Wood, R.: Organic matter and non-refractory aerosol over the remote Southeast Pacific: oceanic and combustion sources, Atmos. Chem. Phys., 12, 557-576, doi:10.5194/acp-12-557-2012, 2012.

Sievering, H., Lerner, B., Slavich, J., Anderson, J., Posfai, M., and Cainey, J.: $\mathrm{O}_{3}$ oxidation of $\mathrm{SO}_{2}$ in sea-salt aerosol water: Size distribution of non-sea-salt sulfate during the First Aerosol Characterization Experiment (ACE 1), J. Geophys. Res.-Atmos., 104, 21707-21717, doi:10.1029/1998jd100086, 1999. 
Silva, P., Liu, D.-Y., Noble, C. A., and Prather, K. A.: Size and chemical characterization of individual particles resulting from biomass burning of local southern California species, Environ. Sci. Technol., 33, 3068-3076, 1999.

Skamarock, W. C., Klemp, J. B., Dudhia, J., Gill, D. O., Barker, D. M., Duda, M. G., Huang, X.-Y., Wang, W., and Powers, J. G.: A Description of the Advanced Research WRF, Version 3, Technical Report NCAR/TN475+ST Boulder, CO, 2008.

Snider, J. R. and Brenguier, J. L.: Cloud condensation nuclei and cloud droplet measurements during ACE-2, Tellus B, 52, 828842, 2000.

Solomon, S., Qin, D., Manning, M., Marquis, M., Averyt, K., Tignor, M. M. B., Jr., H. L. M., and Chen, Z.: Climate Change 2007: Working Group I: The Physical Science Basis, Intergovernmental Panel on Climate Change, 996, 2007.

Spak, S. N., Mena-Carrasco, M. A., and Carmichael, G. R.: Atmospheric transport of anthropogenic oxidized sulfur over the Southeast Pacific during VOCALS REx, CLIVAR Exchanges, 53, 20-21, 2010.

Stephens, G. L.: Radiation Profiles in Extended Water Clouds .2. Parameterization Schemes, J. Atmos. Sci., 35, 2123-2132, 1978.

Stevens, B. and Feingold, G.: Untangling aerosol effects on clouds and precipitation in a buffered system, Nature, 461, 607-613, doi:10.1038/Nature08281, 2009.

Stevens, B., Moeng, C. H., Ackerman, A. S., Bretherton, C. S., Chlond, A., De Roode, S., Edwards, J., Golaz, J. C., Jiang, H. L., Khairoutdinov, M., Kirkpatrick, M. P., Lewellen, D. C., Lock, A., Muller, F., Stevens, D. E., Whelan, E., and Zhu, P.: Evaluation of large-Eddy simulations via observations of nocturnal marine stratocumulus, Mon. Weather Rev., 133, 1443-1462, doi:10.1175/mwr2930.1, 2005a.

Stevens, B., Vali, G., Comstock, K., Wood, R., van Zanten, M. C., Austin, P. H., Bretherton, C. S., and Lenschow, D. H.: Pockets of open cells and drizzle in marine stratocumulus, B. Am. Meteorol. Soc., 86, 51-57, doi:10.1175/Bams-86-1-51, 2005b.

Stohl, A., Forster, C., Frank, A., Seibert, P., and Wotawa, G.: Technical note: The Lagrangian particle dispersion model FLEXPART version 6.2, Atmos. Chem. Phys., 5, 2461-2474, doi:10.5194/acp-5-2461-2005, 2005.

Toniazzo, T., Abel, S. J., Wood, R., Mechoso, C. R., Allen, G., and Shaffrey, L. C.: Large-scale and synoptic meteorology in the south-east Pacific during the observations campaign VOCALSREx in austral Spring 2008, Atmos. Chem. Phys., 11, 49775009, doi:10.5194/acp-11-4977-2011, 2011.

Tsapakis, M., Lagoudaki, E., Stephanou, E. G., Kavouras, I. G., Koutrakis, P., Oyola, P., and von Baer, D.: The composition and sources of PM2.5 organic aerosol in two urban areas of Chile, Atmos. Environ., 36, 3851-3863, doi:10.1016/s13522310(02)00269-8, 2002.

Twohy, C. H.: Airborne Condensation Nucleus Counter User's Guide, National Center for Atmospheric Research, 21, 1991.

Twohy, C. H. and Hudson, J. G.: Measurements of Cloud Condensation Nuclei Spectra within Maritime Cumulus Cloud Droplets Implications for Mixing Processes, J. Appl. Meteorol., 34, 815833, 1995.

Twohy, C. H., Austin, P. H., and Charlson, R. J.: Chemical consequences of the initial diffusional growth of cloud droplets: a clean marine case, Tellus B, 41, 51-60, doi:10.1111/j.16000889.1989.tb00124.x, 1989a.
Twohy, C. H., Clarke, A. D., Warren, S. G., Radke, L. F., and Charlson, R. J.: Light-Absorbing Material Extracted from Cloud Droplets and Its Effect on Cloud Albedo, J. Geophys. Res.Atmos., 94, 8623-8631, 1989b.

Twohy, C. H., Strapp, J. W., and Wendisch, M.: Performance of a counterflow virtual impactor in the NASA Icing Research Tunnel, J. Atmos. Ocean. Tech., 20, 781-790, 2003.

Twohy, C. H., Petters, M. D., Snider, J. R., Stevens, B., Tahnk, W., Wetzel, M., Russell, L., and Burnet, F.: Evaluation of the aerosol indirect effect in marine stratocumulus clouds: Droplet number, size, liquid water path, and radiative impact, J. Geophys. Res.Atmos., 110, D08203, doi:10.1029/2004jd005116, 2005.

Twohy, C. H., Coakley, J. A., and Tahnk, W. R.: Effect of changes in relative humidity on aerosol scattering near clouds, J. Geophys. Res.-Atmos., 114, D05205, doi:10.1029/2008jd010991, 2009.

Twomey, S.: Pollution and Planetary Albedo, Atmos. Environ., 8, 1251-1256, 1974.

Wallace, J. M. and Hobbs, P. V.: Atmospheric Science: An Introductory Survey, Academic Press, 467 pp., 1977.

Wang, Z., French, J., Vali, G., Wechsler, P., Haimov, S., Rodi, A., Deng, M., Leon, D., Snider, J., Peng, L., and Pazmany, A. L.: Single Aircraft Integration of Remote Sensing and In Situ Sampling for the Study of Cloud Microphysics and Dynamics, B. Am. Meteorol. Soc., 93, 653-668, doi:10.1175/bams-d-11-00044.1, 2012.

Weber, R. J., Clarke, A. D., Litchy, M., Li, J., Kok, G., Schillawski, R. D., and McMurry, P.: Spurious aerosol measurements when sampling from aircraft in the vicinity of clouds, J. Geophys. Res., 103, 28337-28346, 1998.

Wood, R.: Cancellation of aerosol indirect effects in marine stratocumulus through cloud thinning, J. Atmos. Sci., 64, 26572669, doi:10.1175/jas3942.1, 2007.

Wood, R., Bretherton, C. S., and Hartmann, D. L.: Diurnal cycle of liquid water path over the subtropical and tropical oceans, Geophys. Res. Lett., 29, 2092, doi:10.1029/2002g1015371, 2002.

Wood, R., Bretherton, C. S., Leon, D., Clarke, A. D., Zuidema, P., Allen, G., and Coe, H.: An aircraft case study of the spatial transition from closed to open mesoscale cellular convection over the Southeast Pacific, Atmos. Chem. Phys., 11, 2341-2370, doi:10.5194/acp-11-2341-2011, 2011a.

Wood, R., Mechoso, C. R., Bretherton, C. S., Weller, R. A., Huebert, B., Straneo, F., Albrecht, B. A., Coe, H., Allen, G., Vaughan, G., Daum, P., Fairall, C., Chand, D., Gallardo Klenner, L., Garreaud, R., Grados, C., Covert, D. S., Bates, T. S., Krejci, R., Russell, L. M., de Szoeke, S., Brewer, A., Yuter, S. E., Springston, S. R., Chaigneau, A., Toniazzo, T., Minnis, P., Palikonda, R., Abel, S. J., Brown, W. O. J., Williams, S., Fochesatto, J., Brioude, J., and Bower, K. N.: The VAMOS Ocean-Cloud-AtmosphereLand Study Regional Experiment (VOCALS-REx): goals, platforms, and field operations, Atmos. Chem. Phys., 11, 627-654, doi:10.5194/acp-11-627-2011, 2011 b.

Wyant, M. C., Wood, R., Bretherton, C. S., Mechoso, C. R., Bacmeister, J., Balmaseda, M. A., Barrett, B., Codron, F., Earnshaw, P., Fast, J., Hannay, C., Kaiser, J. W., Kitagawa, H., Klein, S. A., Köhler, M., Manganello, J., Pan, H.-L., Sun, F., Wang, S., and Wang, Y.: The PreVOCA experiment: modeling the lower troposphere in the Southeast Pacific, Atmos. Chem. Phys., 10, 4757-4774, doi:10.5194/acp-10-4757-2010, 2010. 
Yang, M., Huebert, B. J., Blomquist, B. W., Howell, S. G., Shank, L. M., McNaughton, C. S., Clarke, A. D., Hawkins, L. N., Russell, L. M., Covert, D. S., Coffman, D. J., Bates, T. S., Quinn, P. K., Zagorac, N., Bandy, A. R., de Szoeke, S. P., Zuidema, P. D., Tucker, S. C., Brewer, W. A., Benedict, K. B., and Collett, J. L.: Atmospheric sulfur cycling in the southeastern Pacific longitudinal distribution, vertical profile, and diel variability observed during VOCALS-REx, Atmos. Chem. Phys., 11, 50795097, doi:10.5194/acp-11-5079-2011, 2011a.

Yang, Q., Gustafson Jr., W. I., Fast, J. D., Wang, H., Easter, R. C., Morrison, H., Lee, Y.-N., Chapman, E. G., Spak, S. N., and Mena-Carrasco, M. A.: Assessing regional scale predictions of aerosols, marine stratocumulus, and their interactions during VOCALS-REx using WRF-Chem, Atmos. Chem. Phys., 11, 11951-11975, doi:10.5194/acp-11-11951-2011, 2011 b.

Yang, Q., Gustafson Jr., W. I., Fast, J. D., Wang, H., Easter, R. C., Wang, M., Ghan, S. J., Berg, L. K., Leung, L. R., and Morrison, H.: Impact of natural and anthropogenic aerosols on stratocumulus and precipitation in the Southeast Pacific: a regional modelling study using WRF-Chem, Atmos. Chem. Phys., 12, 87778796, doi:10.5194/acp-12-8777-2012, 2012.
Zaveri, R. A. and Peters, L. K.: A new lumped structure photochemical mechanism for large-scale applications, J. Geophys. Res.Atmos., 104, 30387-30415, doi:10.1029/1999jd900876, 1999.

Zaveri, R. A., Easter, R. C., Fast, J. D., and Peters, L. K.: Model for Simulating Aerosol Interactions and Chemistry (MOSAIC), J. Geophys. Res.-Atmos., 113, D13204, doi:10.1029/2007jd008782, 2008.

Zheng, X., Albrecht, B., Jonsson, H. H., Khelif, D., Feingold, G., Minnis, P., Ayers, K., Chuang, P., Donaher, S., Rossiter, D., Ghate, V., Ruiz-Plancarte, J., and Sun-Mack, S.: Observations of the boundary layer, cloud, and aerosol variability in the southeast Pacific near-coastal marine stratocumulus during VOCALSREx, Atmos. Chem. Phys., 11, 9943-9959, doi:10.5194/acp-119943-2011, 2011.

Zuidema, P., Leon, D., Pazmany, A., and Cadeddu, M.: Aircraft millimeter-wave passive sensing of cloud liquid water and water vapor during VOCALS-REx, Atmos. Chem. Phys., 12, 355-369, doi:10.5194/acp-12-355-2012, 2012. 